\title{
An experimental study to investigate the physical and dynamic elastic properties of Eagle Ford shale rock samples
}

\author{
Faisal Altawati ${ }^{1}\left[\right.$. Hossein Emadi ${ }^{1} \cdot$ Rayan Khalil $^{2}$
}

Received: 4 February 2021 / Accepted: 19 July 2021 / Published online: 26 July 2021

(c) The Author(s) 2021

\begin{abstract}
Unconventional resources, such as Eagle Ford formation, are commonly classified for their ultra-low permeability, where pore sizes are in nano-scale and pore-conductivity is low, causing several challenges in evaluating unconventional-rock properties. Several experimental parameters (e.g., diffusion time of gas, gas injection pressure, method of permeability measurement, and confining pressure cycling) must be considered when evaluating the ultra-low permeability rock's physical and dynamic elastic properties measurements, where erroneous evaluations could be avoided. Characterizing ultra-low permeability samples' physical and elastic properties helps researchers obtain more reliable information leading to successful evaluations. In this study, 24 Eagle Ford core samples' physical and dynamic elastic properties were evaluated. Utilizing longer diffusion time and higher helium injection pressure, applying complex transient method, and cycling confining pressure were considered for porosity, permeability, and velocities measurements. Computerized tomography (CT) scan, porosity, permeability, and ultrasonic wave velocities were conducted on the core samples. Additionally, X-ray Diffraction (XRD) analysis was conducted to determine the mineralogical compositions. Porosity was measured at 2.07 MPa injection pressure for $24 \mathrm{~h}$, and the permeability was measured using a complex transient method. P- and S-wave velocities were measured at two cycles of five confining pressures (up to 68.95 MPa). The XRD analysis results showed that the tested core samples had an average of $81.44 \%$ and $11.68 \%$ calcite and quartz, respectively, with a minor amount of clay minerals. The high content of calcite and quartz in shale yields higher velocities, higher Young's modulus, and lower Poisson's ratio, which enhances the brittleness that is an important parameter for well stimulation design (e.g., hydraulic fracturing). The results of porosity and permeability showed that porosity and permeability vary between $5.3-9.79 \%$ and $0.006-12 \mu \mathrm{D}$, respectively. The Permeability-porosity relation of samples shows a very weak correlation. P- and S-wave velocities results display a range of velocity up to $6206 \mathrm{~m} / \mathrm{s}$ and $3285 \mathrm{~m} / \mathrm{s}$ at $68.95 \mathrm{MPa}$ confining pressure, respectively. Additionally, S-wave velocity is approximately $55 \%$ of $\mathrm{P}$-wave velocity. A correlation between both velocities is established at each confining pressure, indicating a strong correlation. Results illustrated that applying two cycles of confining pressure impacts both velocities and dynamic elastic moduli. Ramping up the confining pressure increases both velocities owing to compaction of the samples and, in turn, increases dynamic Young's modulus and Poisson's ratio while decreasing bulk compressibility. Moreover, the results demonstrated that the above-mentioned parameters' values (after decreasing the confining pressure to $13.79 \mathrm{MPa}$ ) differ from the initial values due to the hysteresis loop, where the loop is slightly opened, indicating that the alteration is non-elastic. The findings of this study provide detailed information about the rock physical and dynamic elastic properties of one of the largest unconventional resources in the U.S.A, the Eagle Ford formation, where direct measurements may not be cost-effective or feasible.
\end{abstract}

Keywords Unconventional reservoir $\cdot$ Eagle Ford $\cdot$ Porosity $\cdot$ Permeability $\cdot$ Ultrasonic wave velocity $\cdot$ Elastic moduli

Faisal Altawati

faisal.altawati@ttu.edu

1 Bob L. Herd Department of Petroleum Engineering, Texas Tech University, Texas, USA

2 Department of Petroleum Geology and Sedimentology, King Abdulaziz University, Jeddah, Saudi Arabia 


$\begin{array}{ll}\text { Abbreviations } \\ \text { CT-scan } & \text { Computerized tomography scan } \\ \text { XRD } & \text { X-ray diffraction } \\ \text { GRI } & \text { Gas Research Institute } \\ \text { NMR } & \text { Nuclear Magnetic Resonance } \\ \text { NER } & \text { New England Research } \\ \text { List of symbols } \\ \text { MPa } & \text { Megapascal pressure unit } \\ \mathrm{mD} & \text { Milli-Darcy permeability unit } \\ \mu \mathrm{D} & \text { Micro-Darcy permeability unit } \\ \mathrm{nD} & \text { Nano-Darcy permeability unit } \\ \mathrm{kV} & \text { Kilovolt electromotive force unit } \\ \mathrm{mA} & \text { Milliampere electric current unit } \\ \mathrm{g} / \mathrm{mol} & \text { Gram per mole molar mass unit } \\ \mathrm{pm} & \text { Picometer kinetic diameter unit } \\ \mathrm{o}_{2} \theta & \text { Degrees 2-theta diffraction angle unit } \\ \mathrm{lp} / \mathrm{mm} & \text { Line pairs per millimeter spatial resolution } \\ V_{1} & \text { Volume in Cell-1, cm }{ }^{3} \\ V_{2} & \text { Total volume of the setup, cm } \\ P_{1} & \text { Initial pressure in Cell-1, MPa } \\ P_{2} & \text { Expansion pressure in the system } \\ E_{\mathrm{d}} & \text { Dynamic Young's modulus, GPa } \\ V_{\mathrm{d}} & \text { Dynamic Poisson's ratio, unitless } \\ C_{\mathrm{b}} & \text { Bulk compressibility, } / \mathrm{MPa} \\ B_{\mathrm{r}} & \text { Brittleness ratio, unitless } \\ V_{\mathrm{P}} & \text { Primary/compressional wave (P-wave) velocity, } \\ & \text { m/s } \\ V_{\mathrm{S}} & \text { Secondary/shear wave (S-wave) velocity, } \mathrm{m} / \mathrm{s} \\ \rho & \text { Bulk density of the rock, g/cm }{ }^{3} \\ \varnothing & \text { Porosity, } \% \\ k_{\mathrm{g}} & \text { Gas permeability, } \mu \mathrm{D} \\ V_{\mathrm{S} 1} & \text { Fast shear-velocity } 1, \mathrm{~m} / \mathrm{s} \\ V_{\mathrm{S} 2} & \text { Slow shear velocity } 2, \mathrm{~m} / \mathrm{s} \\ R^{2} & \text { Coefficient of determination } \\ \Delta & \text { Change } \\ & \end{array}$

\section{Introduction}

Unconventional resources (e.g., shale oil and shale gas) are commonly defined as reservoirs that have ultra-low permeability in micro-Darcy $(\mu \mathrm{D})$ to nano-Darcy $(\mathrm{nD})$ scale. Using the combination of horizontal wells and multistage transverse hydraulic fracturing, hydrocarbon production from unconventional formations has become practical and economically feasible. Over the last years, these unconventional formations have become the primary sources of hydrocarbons in the U.S. A proper understanding of shale physical and mechanical properties is essential for many aspects, such as reserve estimation, hydrocarbon production prediction and improvement, and carbon sequestration. Several challenges are encountered in laboratory-based measurements since unconventional formations have ultra-low permeability, less than $10 \%$ porosity, and complex mineralogical compositions.

Several techniques are used to experimentally measure the porosity, including Nuclear Magnetic Resonance (NMR), mercury capillary pressure, and immersion porosimetry method (Kuila et al. 2014; Sigal 2013; Yao et al. 2010). The gas expansion or gas injection porosimeter technique, a widely used one, is another method that can measure effective porosity. Some challenges, such as gas injection pressure and the dimension of core plugs, are associated with this technique (Sun et al. 2016). Using this method, gas is simply injected into Cell-1 (known as reference cell) at a specific pressure, and then Cell-1 is opened and connected to Cell-2 (sample cell) to drive gas molecules into the sample's pores. Then, Boyle's law at the isothermal condition is used to calculate the grain volume, Eq. (1):

$V_{1} P_{1}=V_{2} P_{2}$

where $\mathrm{V}_{1}$ is the volume in Cell- $1, \mathrm{~V}_{2}$ is the total volume of the setup, $\mathrm{P}_{1}$ is the initial pressure in Cell-1, and $\mathrm{P}_{2}$ is the expansion pressure in the system.

One of the essential rock properties is permeability. The permeability of core samples can be measured directly by flowing fluid through the rock and indirectly using the NMR method. There are two direct techniques to measure permeability depending on the flow regime: steady-state and unsteady-state methods. The steady-state method is considered the standard practice to measure the permeability of different rocks in the laboratory (Amann-Hildenbrand et al. 2013; Gensterblum et al. 2014; Li et al. 2009; Profice et al. 2016; Rushing et al. 2004; Tanikawa and Shimamoto 2009), and its experimental setup, procedure, and analytical solution make it a reliable technique. However, its application to ultra-low permeability rocks is believed to be impractical due to its time-consuming process for measuring the tremendously low flow rates and small pressure drops (Cui et al. 2009). The second method to measure the permeability is the unsteady-state method. A transient flow method, which is based on the single-phase flow and pressure transient analysis introduced by Brace et al. (1968) to determine Westerly granite permeability. Many methods have been developed and proposed to measure the permeability of lowpermeable rocks. There are three unsteady-state methods; pressure-pulse decay method, Gas Research Institute (GRI) method, and oscillating pressure method. Pressure-pulse and modified pressure-pulse decay methods are appeared to be reliable techniques to measure the permeability of low-permeable samples (Aljamaan et al. 2013; Alnoaimi and Kovscek 2013; Badrouchi et al. 2019; Billiotte et al. 2008; Cao et al. 2016; Cui et al. 2009; Dicker and Smits 1988; Firouzi 
et al. 2014; Heller et al. 2014; Hildenbrand et al. 2002; Jones 1997; Kim et al. 2020; Lin et al. 1986; Metwally and Sondergeld 2011; Mokhtari and Tutuncu 2015; Pan et al. 2015; Zhang et al. 2000). Comparing to the steady-state method, the pressure-pulse decay method is mostly used because of its shorter running times and high-resolution measurement for low-permeable rocks (Cui et al. 2009).

In the oil and gas industry, ultrasonic velocity measurements are performed to estimate hydrocarbon formations' geomechanical properties. The ultrasonic velocities are measured by calculating the travel time of an elastic signal through a rock sample. There are two types of elastic waves: primary or compressional wave (P-wave) and secondary or shear wave (S-wave). $\mathrm{P}$ - and $\mathrm{S}$-wave are longitudinal and transverse waves to the particle displacement direction, respectively, where $\mathrm{P}$-wave travels faster than $\mathrm{S}$-wave. Unlike P-Wave, S-wave can only travel through solid materials. Ultrasonic velocities are commonly used for several reasons: being economically practical, having a short duration of the measurements, and being eco-friendly and non-destructive. Using the results of ultrasonic velocities, dynamic elastic moduli of the rock can be calculated.

Effective stress, porosity, permeability, fluid saturation, mineralogical compositions, pore type, and rock strength of sandstone and carbonate samples have been extensively investigated by several researchers (Anselmetti and Eberli 1993; Chang et al. 2006; Freund 1992; Khaksar et al. 1999; Khazanehdari and Sothcott 2003; Miller 1992; Rafavich et al. 1984; Shakouri et al. 2019; Soete et al. 2015). Several studies have investigated the effects of many parameters, such as gas transport and adsorption effect, pyrolysisinduced thermal maturation, water content, the relationship between static and dynamic properties, temperature, anisotropy, and bedding orientation effects using shale samples (Aljamaan et al. 2017; Aljamaan et al. 2013; Allan et al. 2016; Alnoaimi* et al. 2014; Guo et al. 2013; He et al. 2019; Holt et al. 2015; Holt et al. 2012; Kim et al. 2020; Kuila et al. 2011; Lai et al. 2016; Masri et al. 2014; Sone and Zoback 2013a; Sone and Zoback 2013b; Zhai et al. 2021). However, few studies have conducted to examine the rock physical and/or dynamic elastic properties of shale formations (Badrouchi et al. 2019; Cho et al. 2016; He and Ling 2016; Heller et al. 2014; Khalil et al. 2019; Ramezanian and Emadi 2020; Sun et al. 2016).

Heller et al. (2014) investigated the effects of confining and pore pressures on matrix permeability of gas-shale plugs from Barnett, Eagle Ford, Marcellus, and Montney reservoirs. The results demonstrated that the matrix permeability mainly depends on the confining pressure. Also, they concluded that permeability was substantially improved at low pore pressure less than 3.4 MPa using helium gas. Sun et al. (2016) studied the effect of gas injection pressure on accessible porosity using shale plugs and crushed samples. They concluded that measuring shale porosity is strongly dependent on the gas injection pressure. Also, they concluded that a minimum gas injection pressure of $1.48 \mathrm{MPa}$ and a longer diffusion time are required for accurate porosity measurements of core samples compared to crushed samples. It is worth noting that applying gas injection pressures less than $1.38 \mathrm{MPa}$ results in underestimating the porosity values. Cho et al. (2016) measured samples' porosity and permeability from three unconventional reservoirs, Bakken, Eagle Ford, and Niobrara formations, using GRI-crushed samples analysis. They plotted permeability versus porosity, and adjusted relationships for all three formations were drawn. They observed that even though the lower Eagle Ford and Niobrara samples' mineralogical compositions are similar, the lower Eagle Ford cores have lower permeability values.

He and Ling (2016) measured the permeability of six core samples from middle Bakken formation using one setup and three methods (oscillating pulse, downstream pressure buildup, and radius-of-investigation) to reduce uncertainty. The results indicated that the permeabilities from the three methods show fair agreements with a range of uncertainty. The results showed that using three methods to measure the low permeability samples would help model the uncertainties associated with permeability and porosity. Badrouchi et al. (2019) compared different permeability measurement methods (steady-state, aspike, and multi-pulse methods) using core samples from Bakken formation. The steady-state method is subjected to overestimating the matrix permeability of low-permeable samples due to the high-flow resistivity that might diffuse and flow between the sleeve and the sample's wall. The steady-state method is not applicable for very tight samples because the flow does not comply with Darcy's law. The permeability results from unsteady-state methods (aspike and multi-pulse) demonstrated that the aspike method showed higher permeability values (10 times) than the multi-pulse method. The aspike method is more suitable for samples that have higher permeability values $(>1 \mathrm{mD})$. The multi-pulse method results showed that this method could reduce anisotropy and heterogeneity effects.

Khalil et al. (2019) measured samples' porosity from Marcellus formation at four injection pressures $(0.69,1.38$, 2.07 , and $2.76 \mathrm{MPa}$ ). The results showed a direct relationship between the injection pressure and the measured porosity. They concluded that the optimum injection pressure to measure the samples' porosities accurately is $1.38 \mathrm{MPa}$. The results showed that porosity values range from 6 to $14 \%$. Additionally, they measured the permeability and ultrasonic velocities of the samples. Permeability values vary from $4.69 \mathrm{nD}$ to $153 \mathrm{nD}$, which is considered ultra-low permeabilities. The velocity measurement results demonstrated that as confining pressure increases (from 5.17 to $29.23 \mathrm{MPa}$ ), compressional and shear velocities also increase. However, no correlations were established in this study. Ramezanian 
and Emadi (2020) investigated the effects of temperature and confining pressure on dynamic elastic properties and permeability of four different shale rock samples. The results illustrated that increasing confining pressure (up to $34.5 \mathrm{MPa}$ ) increases rock stiffness while increasing the temperature (up to $100^{\circ} \mathrm{C}$ ) makes the rock more plastic and decreases permeability. They found out that there is an inverse relationship between temperature and ultrasonic wave velocities. They observed that temperature is the dominant factor in making the rock samples more ductile even at elevated confining pressures.

In the previous works, the physical and dynamic elastic properties of sandstone and carbonate samples were extensively investigated. On the other hand, few studies examining shale samples' physical and/or dynamic elastic properties were conducted. Apart from previous experimental investigations using shale samples, some experimental parameters (e.g., using longer diffusion time of gas, utilizing higher gas injection pressure, applying complex transient method, and cycling the confining pressure) were not thoroughly considered when investigating the physical and dynamic elastic properties of the ultra-low permeability samples. In this study, considering these experimental parameters, porosity, permeability, and ultrasonic velocities of 24 unsaturated Eagle Ford core samples were experimentally investigated. This study aims to provide and add detailed information when it comes to the evaluations of rock physical and dynamic elastic properties of one of the largest unconventional resources in the U.S.A, the Eagle Ford formation, where direct measurements may not be cost-effective or feasible. For example, the S-wave velocity can be calculated using the less expensive P-wave velocity data when an established correlation between P- and S-wave velocities is available.

(a)

- Unconventional resources are commonly classified for their ultra-low permeability, where pore sizes are in nano-scale and pore-conductivity is low, causing several challenges in evaluating unconventional-rock properties.

- In the previous works, several experimental parameters, such as using longer diffusion time of gas, utilizing higher gas injection pressure, applying complex transient method, and cycling the confining pressure, were not thoroughly considered when evaluating the physical and dynamic elastic properties of the ultra-low permeability samples.

- Characterizing ultra-low permeability samples' (e.g., Eagle Ford samples) physical and dynamicelastic properties, with taking these experimental parameters into account, helps researchers obtain more reliable information leading to successful evaluations.

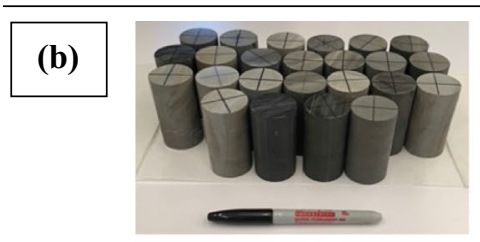

24 EF core samples $(\mathrm{L}=7.62 \mathrm{~cm}$, $\mathrm{D}=3.81 \mathrm{~cm})$

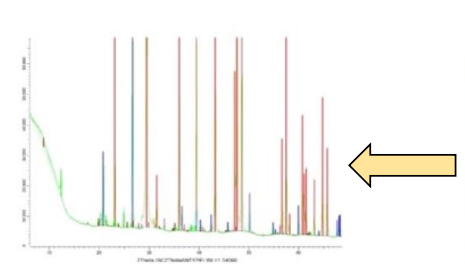

XRD analysis.

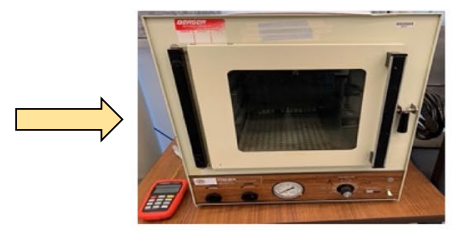

Dried in a vacuum oven at $65^{\circ} \mathrm{C}$

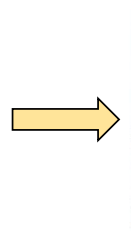

CT-scanned the samples with 1.25 $\mathrm{lp} / \mathrm{mm}$ of spatial resolution

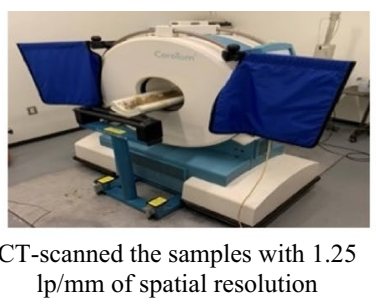

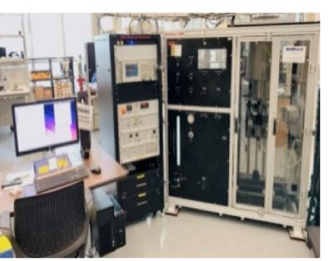

Measured permeability (net eff. press $=5.52 \mathrm{MPa}$ ) and ultrasonic velocity (at two cycles of five confining pressures up to $68.95 \mathrm{MPa}$ )

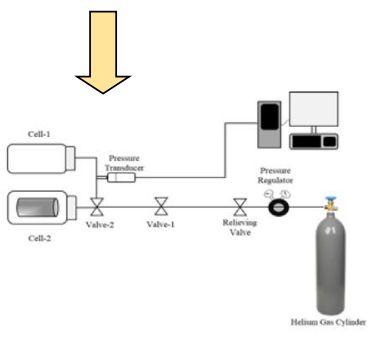

Measured porosity at injectionpressure $=2.07 \mathrm{MPa}$ for $24 \mathrm{hrs}$.

Fig. 1 a General sketch of the problems presented in this study and $\mathbf{b}$ Core samples preparation and methods 
Figure $1 \mathrm{a}$ and $\mathrm{b}$ show the general sketch of the problems presented in this study and the methodology and procedure adopted, respectively. As shown in Fig. 1b, at first, all samples were prepared and dried in a vacuum oven for $48 \mathrm{~h}$. Then, CT scanner was used to identify any fracture(s) in the tested samples. Additionally, a helium porosimeter setup was assembled, and the samples' porosity was measured at 2.07 MPa for $24 \mathrm{~h}$. Next, using AutoLab 1500 system, samples' permeability was measured by applying a complex transient method (multi-pulse). Furthermore, P- and S-wave velocities were measured using the AutoLab 1500 and ultrasonic transmission method at two cycles of five different confining pressures (up to 68.95 MPa). Finally, using ten samples in this study, XRD analysis was conducted to determine mineralogical compositions.

\section{Materials and methods}

\section{Materials}

Twenty-four outcropped and unsaturated core samples from Eagle Ford of West Texas $(7.62 \mathrm{~cm}$ in length and $3.81 \mathrm{~cm}$ in diameter) cut parallel to the bedding planes were used in this study. The samples were numbered, and their endsurfaces were ground (flatness was $\sim \pm 0.01 \mathrm{~mm}$ ) and polished to ensure accurate measurements. It is worth noting that all samples were dried in a vacuum oven at $65^{\circ} \mathrm{C}$ until the samples' weight stabilized ( $48 \mathrm{~h}$ ) to remove any existing free-water and moisture. Then, their dry weights were measured, and several measurements of length and diameter were taken and averaged to avoid any irregularity.

\section{Methods}

In this experimental study, five experiments were conducted on the samples: CT-scan, porosity, permeability, ultrasonic velocities (P- and $\mathrm{S}$-wave velocities), and XRD analysis. It is worth noting that all tests were conducted at an ambient temperature of $22{ }^{\circ} \mathrm{C}$.

A CT scanner is a diagnostic tomography device that uses a series of X-rays taken from different angles of the tested object and a computer to process and create crosssectional images (slices). These slices can be stacked and reformatted in multiple planes. The oil and gas industry has utilized this technology for many purposes, such as identifying any fracture(s) in the tested rock samples. In this study, the NL3000 CereTom ${ }^{\circledR}$ CT scanner was used to detect any existing fracture(s) inside the samples. The scanner has 8-slice configurations, $100-140 \mathrm{kV}$ of tube voltage, 1-7 mA current, 2-6 s of the rotation time range, and $64 \mathrm{~cm}$ of scanning rage. After each full rotation, there is an image

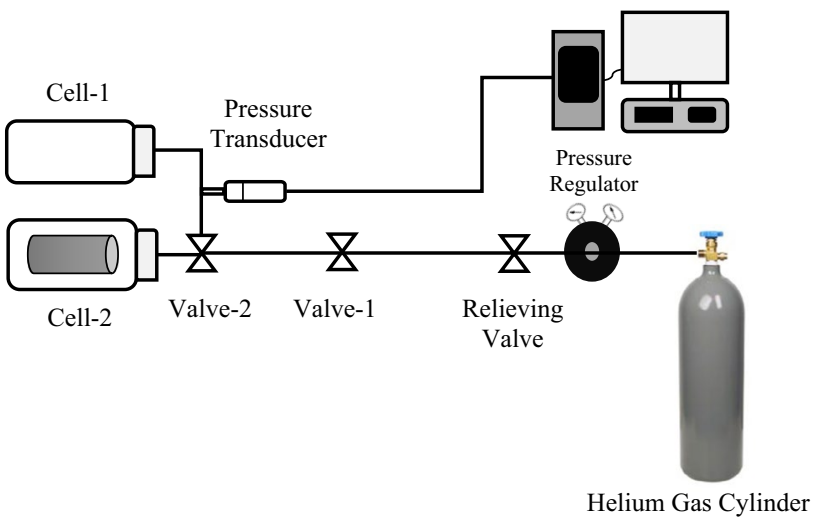

Fig. 2 Schematic diagram of helium porosimeter setup

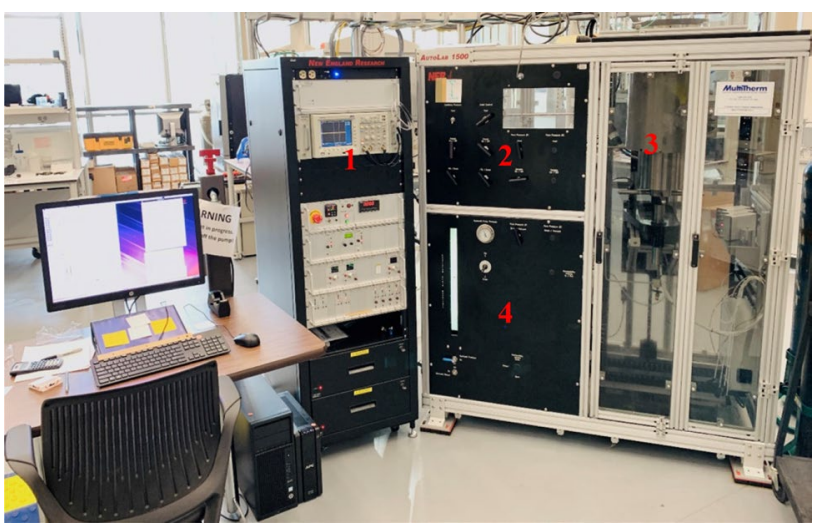

Fig. 3 AutoLab 1500 for permeability and ultrasonic measurements:(1) Digital panel (2) Controlling valves (3) Core holder and core assembly (4) Pressure intensifiers

that has eight slices scanned, and each slice has $1.25 \mathrm{~mm}$ of thickness.

A porosimeter setup (Fig. 2) was assembled to measure the core samples' porosity. All porosity measurements were performed at $2.07 \mathrm{MPa}$ injection pressure for $24 \mathrm{~h}$ to reach pressure equilibrium using helium gas. Using helium gas in low-permeable rocks $(<0.01 \mathrm{mD})$, the pressure equilibrium may take longer testing and diffusion times (Sun et al. 2016).

Due to the extremely low permeability of the core samples (in order of $\mathrm{nD}$ ), using the steady-state method becomes too long and impractical, especially when the flowing fluid is liquid. Hence, in this study, the tested samples' permeability was measured using an unsteady-state method (transient pulse decay method) combined with helium gas. AutoLab 1500 system (Fig. 3) and low permeability sample assembly (Fig. 4a) were used to measure the samples' permeability.

After preparing and jacketing the test sample, the sample assembly was placed inside the high-pressure vessel and filled with mineral oil. The confining and pore pressures were then increased in the system until a net effective stress

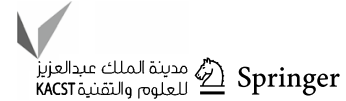




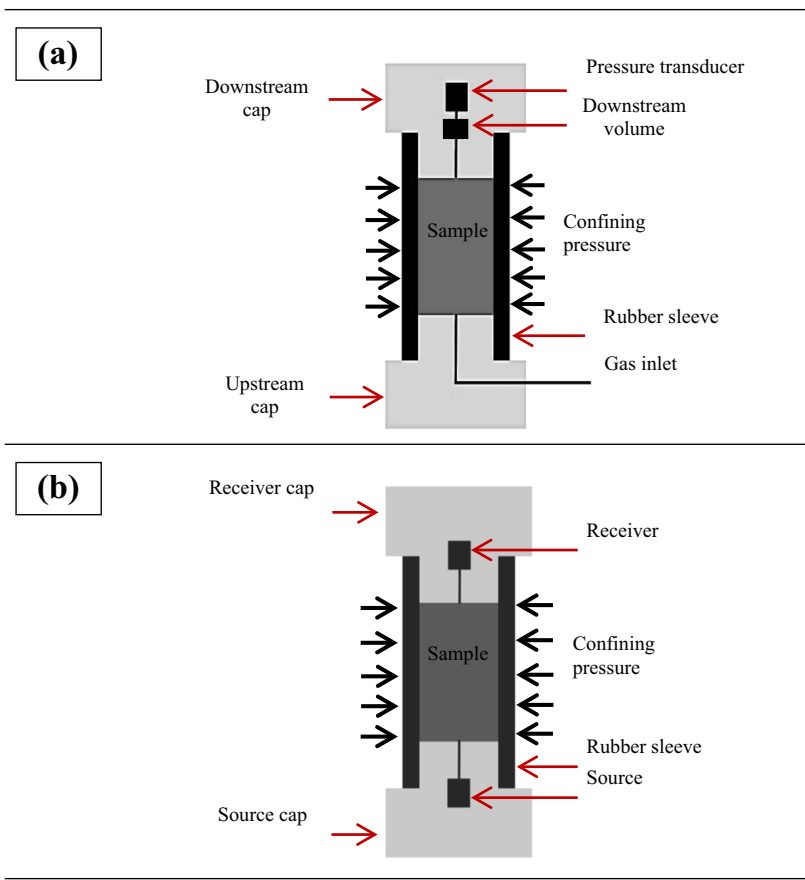

Fig. 4 a Core sample assembly of low permeability, and b Ultrasonic velocity measurements

of 5.52 MPa was reached. It is worth noting that the confining pressure was gently increased at a rate of $0.015 \mathrm{MPa} / \mathrm{s}$ to prevent the creation of any crack(s) in the samples, and it was kept higher than pore pressure to avoid any gas-flow bypass around the test sample. Afterward, helium, as pore fluid, was injected into the sample. The confining pressure, upstream pressure, and temperature were maintained constant throughout the test. After reaching pressure equilibrium, which may take up to $27 \mathrm{~h}$, the sample's permeability was measured using the multi-pulse method. First, the upstream pressure was decreased by $0.86 \mathrm{MPa}$ and maintained constant for few minutes ( eight minutes), then it was increased by $1.72 \mathrm{MPa}$ and kept stable for the same period. Lastly, the upstream pressure was decreased back to the equilibrium pore pressure. It is worth noting that helium is an inert and non-adsorptive gas that has significant diffusion $(4.003 \mathrm{~g} / \mathrm{mol}$ of molar mass and kinetic diameter of $260 \mathrm{pm}$ ), which can reduce the gas adsorption effect and access the micro-pores inside the core samples (Aljamaan et al. 2017; Alnoaimi* et al. 2014; API 1998; Cui et al. 2009; Firouzi et al. 2014; Sun et al. 2016). Hence, it was selected for porosity and permeability tests.

$\mathrm{P}$ - and S-waves were measured using the AutoLab 1500 and ultrasonic transmission method. The sample assembly includes two endcaps; two velocity transducer plugs that transmit and receive $\mathrm{P}$ - and $\mathrm{S}$-wave through the test sample (Fig. 4b). Cyclic confining pressure was applied. The ramping up cycle started from $13.78 \mathrm{MPa}$, increased by
13.78 $\mathrm{MPa}$ increment until reaching $68.95 \mathrm{MPa}$, and then ramped down to $13.78 \mathrm{MPa}$ by a decremental of $13.78 \mathrm{MPa}$. One P-wave and two S-wave were recorded at each confining pressure. It should be mentioned that the confining pressure was gradually increased and decreased at a rate of $0.023 \mathrm{MPa} / \mathrm{s}$ to avoid creating any damage in the samples. Additionally, the confining pressure was maintained constant for two minutes, as a relaxation time, before recording the waves to ensure accurate measurements. Using P- and S-wave velocities results, dynamic Young's modulus and Poisson's ratio and bulk compressibility were calculated using the following equations (Fjar et al. 2008; Zoback 2010):

$$
\begin{aligned}
& E_{\mathrm{d}}=\frac{\rho V_{\mathrm{S}}^{2}\left(3 V_{\mathrm{P}}^{2}-4 V_{\mathrm{S}}^{2}\right)}{V_{\mathrm{P}}^{2}-V_{\mathrm{S}}^{2}} \\
& v_{\mathrm{d}}=\frac{V_{\mathrm{P}}^{2}-2 V_{\mathrm{S}}^{2}}{2\left(V_{\mathrm{P}}^{2}-V_{\mathrm{S}}^{2}\right)}
\end{aligned}
$$

$C_{\mathrm{b}}=\frac{1}{\rho V_{\mathrm{P}}^{2}-\frac{4}{3} \rho V_{\mathrm{S}}^{2}}$,

where $E_{d}$ is dynamic Young's modulus, " $\rho$ " is the bulk density of the rock, $V_{S}$ and $V_{P}$ are the $\mathrm{S}$-wave and the P-wave velocities, $v_{d}$ is the dynamic Poisson's ratio, and $C_{b}$ is bulk compressibility. Also, the brittleness of the samples was calculated using the following equation (Rickman et al. 2008):

$B_{\mathrm{r}}=\frac{50}{7}(E-28 v+10.2)$

Finally, using ten samples in this study, X-ray Diffraction (XRD) analysis was conducted to determine the core samples' mineralogical compositions. The samples were crushed and ground into fine powders. The XRD test was performed using a diffractometer that obtained the diffraction patterns from 5 to $70^{\circ} 2 \theta$. The quantification of mineral compositions was completed utilizing a reference intensity ratio method based on the PDF4 + database.

\section{Results and discussion}

The XRD analysis results showed that the samples are rich in calcite with minor compositions of different minerals, such as quartz, muscovite/illite, kaolinite, pyrite, dolomite, sphalerite, bassanite, and ankerite (Fig. 5). Eagle Ford shale rocks are generally considered carbonaceous shale rocks with a minor amount of silica and clays (Sone and Zoback 2013a; Wu et al. 2017). The tested core samples have an average of $81.44 \%$ and $11.68 \%$ calcite and quartz, respectively, 
Fig. 5 Mineralogical compositions of 10 samples

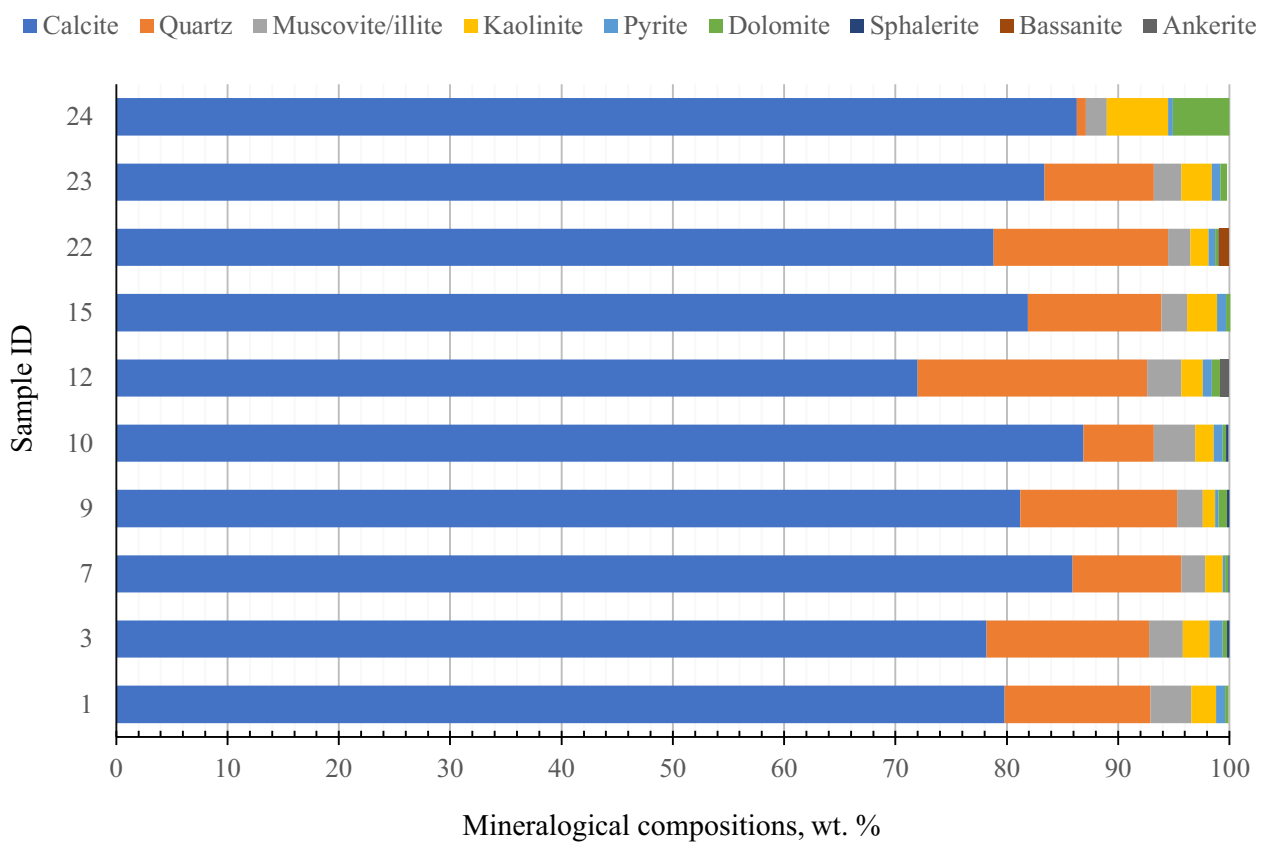

with a minor amount of clay minerals. A higher content of carbonate (calcite and dolomite) and quartz in shale yields higher velocities, higher Young's modulus, and lower Poisson's ratio (Alqahtani et al. 2013; Kumar et al. 2012), which enhances the brittleness properties. On the other hand, existence of high clay content results in increasing rock's ductility and decreasing both velocities, which leads to a slight decrease in Young's modulus and an increase in Poisson's ratio (Alqahtani et al. 2013; Aoudia et al. 2010; Kumar et al. 2012).

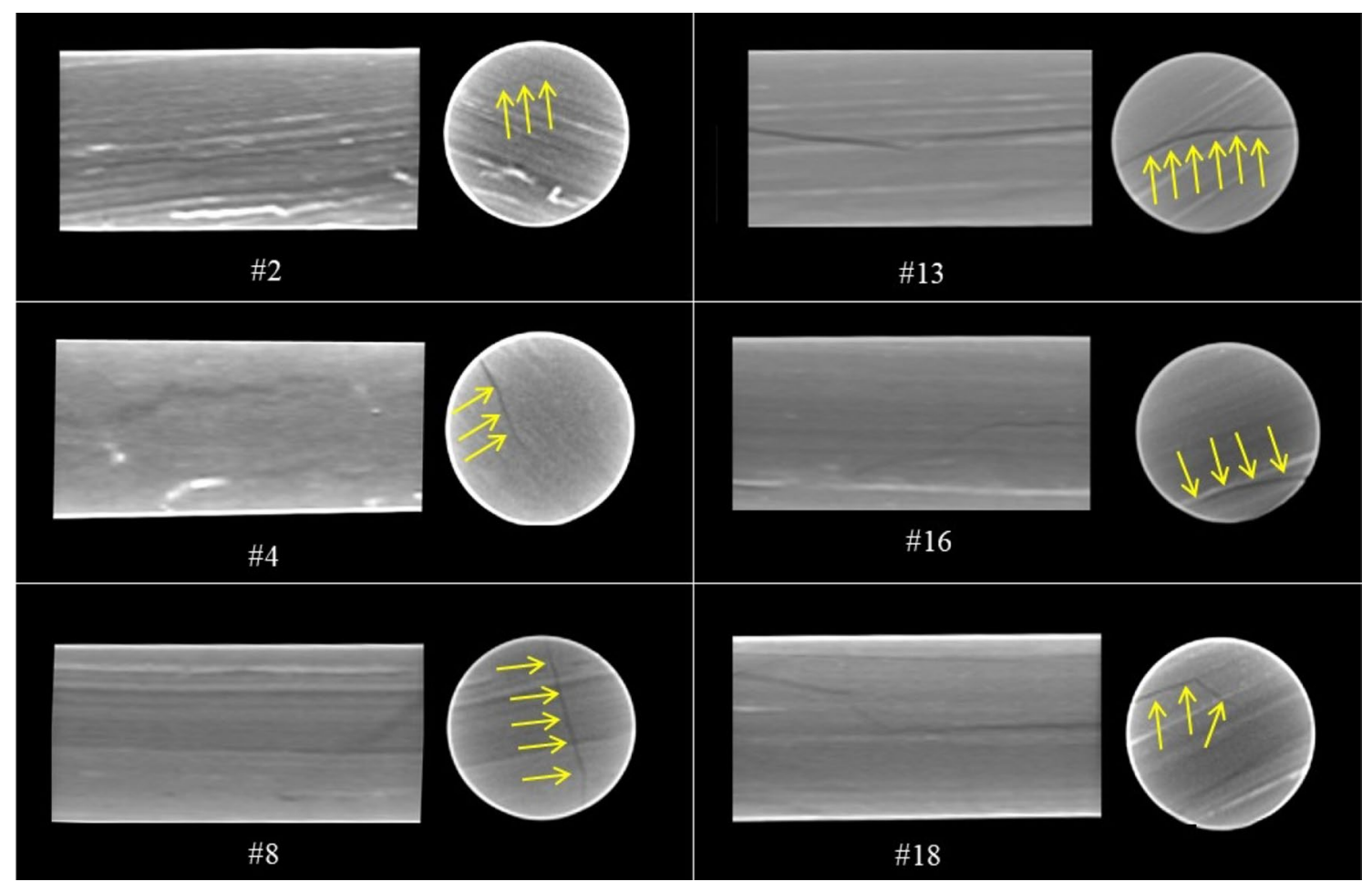

Fig. 6 CT-scan images of samples \#2, \#4, \#8, \#13, \#16, and \#18 in XY and YZ planes 
The CT-scan results revealed that some core samples (\#2, \#4, \#8, \#13, \#16, and \#18) contain fracture(s), as presented in Fig. 6. For instance, the CT-scan image of sample \#13 clearly shows a longitudinal fracture from the top to the bottom of the sample. The orientations of the fractures (e.g., parallel/perpendicular to the sample bedding) are different from one sample to another. Moreover, based on variations in density, the CT-scan results show a visual distribution of different mineralogical compositions in the samples. The presence of $\operatorname{crack}(\mathrm{s})$, as shown in Fig. 6, in the sample significantly affects the permeability value compared to the non-fractured samples, where these fractures provide a high-penetrable pathway for the fluid (gas/liquid) to flow rapidly, resulting in high values of permeability. It is worth noting that the CT-scan used in this study has a spatial resolution of $1.25 \mathrm{lp} / \mathrm{mm}$. The CT scanner detected clear fractures in some core samples (six samples out of 24), and micro-fractures that were near to or below the CT-scan resolution were not detected. Using a micro-CT scanner can assist in getting more accurate information and detecting

Table 1 Summary of determined petrophysical properties of the tested Eagle Ford core samples

\begin{tabular}{|c|c|c|c|c|}
\hline Sample ID & $\begin{array}{l}\text { Bulk density, } \\
\mathrm{g} / \mathrm{cm}^{3}\end{array}$ & $\begin{array}{l}\text { Grain vol- } \\
\text { ume, } \mathrm{cm}^{3}\end{array}$ & $\varnothing, \%$ & $\mathrm{k}_{\mathrm{g}}, \mu \mathrm{D}$ \\
\hline $1 *$ & 2.56 & 80.83 & 6.91 & 0.0076 \\
\hline 2 & 2.22 & 78.37 & 9.12 & 0.6997 \\
\hline $3^{*}$ & 2.56 & 79.82 & 8.00 & 0.2162 \\
\hline 4 & 2.44 & 77.34 & 9.79 & 59.8344 \\
\hline 5 & 2.60 & 79.62 & 6.56 & 0.0078 \\
\hline 6 & 2.62 & 80.76 & 5.30 & 0.0104 \\
\hline $7 *$ & 2.59 & 77.57 & 8.69 & 0.2977 \\
\hline 8 & 2.56 & 77.30 & 8.96 & 1.2022 \\
\hline $9^{*}$ & 2.54 & 77.79 & 8.42 & 0.0196 \\
\hline $10^{*}$ & 2.59 & 78.91 & 7.11 & 0.1465 \\
\hline 11 & 2.48 & 78.22 & 8.41 & 0.0449 \\
\hline $12^{*}$ & 2.52 & 79.10 & 7.13 & 0.0080 \\
\hline 13 & 2.39 & 77.12 & 8.61 & 118.8000 \\
\hline 14 & 2.50 & 78.96 & 7.22 & 0.0105 \\
\hline $15^{*}$ & 2.50 & 78.17 & 8.26 & 0.0074 \\
\hline 16 & 2.49 & 77.48 & 9.03 & 2.6171 \\
\hline 17 & 2.54 & 76.98 & 9.34 & 0.0098 \\
\hline 18 & 2.41 & 76.65 & 11.39 & 25.1173 \\
\hline 19 & 2.66 & 80.95 & 6.45 & 0.0416 \\
\hline 20 & 2.57 & 79.52 & 7.38 & 0.0242 \\
\hline 21 & 2.56 & 77.74 & 9.21 & 0.0060 \\
\hline $22 *$ & 2.55 & 78.50 & 8.48 & 0.1110 \\
\hline $23^{*}$ & 2.63 & 78.19 & 7.47 & 0.0172 \\
\hline $24 *$ & 2.63 & 77.07 & 9.40 & 0.0196 \\
\hline
\end{tabular}

*sample used in XRD analysis any micro-fracture(s) in the core samples that are near to or below the CT-scan imaging resolution used in this study.

The results revealed that the samples' porosity and permeability vary from $5.30 \%$ to $9.79 \%$ and $0.006 \mu \mathrm{D}$ to 11.8 $\mu \mathrm{D}$, respectively. Table 1 summarizes the bulk density, grain volume, porosity, and permeability of the twenty-four samples. Fig. 7 exhibits plots of histogram and boxplot. As shown in Fig. 7a, 50\% of the data show a range of 2.50-2.59 $\mathrm{g} / \mathrm{cm} 3$ of the bulk density, and the median is $2.55 \mathrm{~g} / \mathrm{cm} 3$ with one outlier of $2.22 \mathrm{~g} / \mathrm{cm} 3.75 \%$ of data display that the grain volume is greater than $77.45 \mathrm{~cm} 3$ (Fig. 7b). The samples' median and average porosity are $8.42 \%$ and $8.12 \%$, respectively, and the distribution is a negative-skewed. About $75 \%$ of the data show a porosity that is greater than $7.20 \%$ (Fig. 7c). For the permeability results (Fig. 7d), 75\% of the samples are below $0.398 \mu \mathrm{D}$, where $0.006 \mu \mathrm{D}$ is the lowest measured permeability. The data is not normally distributed (positive-skewed), and the median is $0.0329 \mu \mathrm{D}$.

The results demonstrate an inverse relationship between bulk density and porosity of the samples (Fig. 8a). As the bulk density increases, the porosity decreases. However, the relation between the bulk density and porosity displays a weak correlation. In contrast, the grain volume and porosity cross-plot show an inverse relationship with an acceptable coefficient of determination $(0.77759 \pm 0.092)$.

The results illustrated that permeability values fall into four ranges $(\leq 0.01 \mu \mathrm{D}, 0.01-0.355 \mu \mathrm{D}, 0.356-0.7 \mu \mathrm{D}$, and $>0.7 \mu \mathrm{D})$. The highest permeability values appear in the samples contained fracture(s) (Fig. 6), where some samples (samples \#2, \#4, \#13, and \#18) show high permeability with low bulk density, and samples \#8 and \#16 show high permeability values with higher bulk densities, as shown in Fig. 9. However, since there are no clear and observed relationships between porosity and permeability with bulk density, the origin of the fractures (from natural or coringinduced fractures) is doubtful. It cannot be related to the presence of microcracks or coring process that may have induced crack(s) due to the higher brittleness (higher calcite volume).

It is worth noting that one of the limitations in this study is that the gas slippage effect (known as the Klinkenberg effect) was not taken into account. When the rock's pores are small, near the gas molecules mean free path size, the velocity of gas molecules increases, known as the gas slippage effect, which lowers viscous drag and increases the gas permeability or apparent permeability (Amyx et al. 1960; Firouzi et al. 2014; Klinkenberg 1941; Rushing et al. 2004). Klinkenberg (1941) observed that gas permeability is a function of mean pressure. When the gas/apparent permeability is plotted versus the reciprocal mean pore pressure and the straight-line is extrapolated to the y-axis, the intersection is known as Klinkenberg-corrected permeability or equivalent liquid permeability. However, due to the 


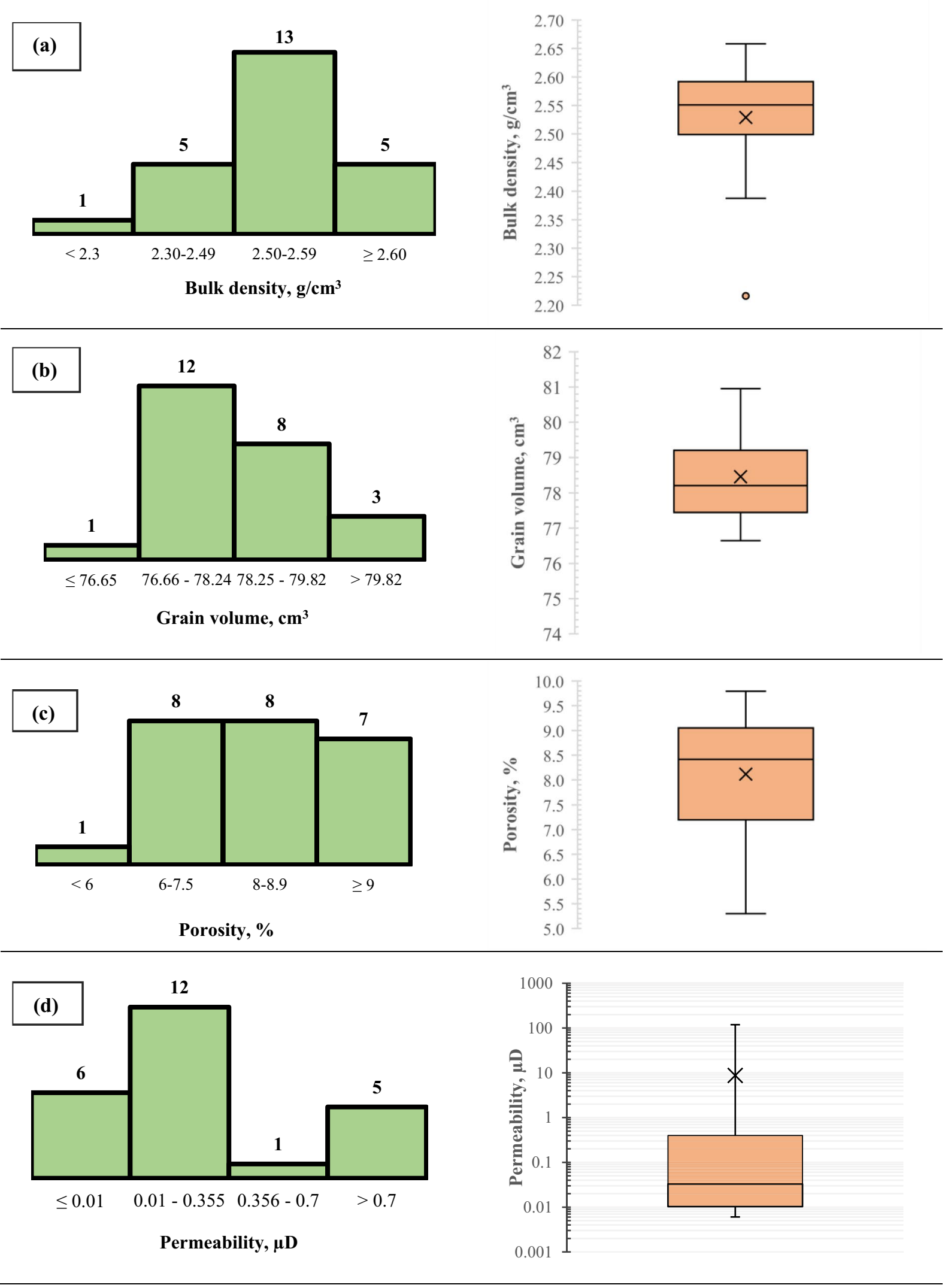

Fig. 7 Statistical plots (histogram and boxplot) of: a bulk density $\mathbf{b}$ grain volume c porosity $\mathbf{d}$ permeability 
Fig. 8 Cross-plot of porosity volume with (a) porosity and (b) grain
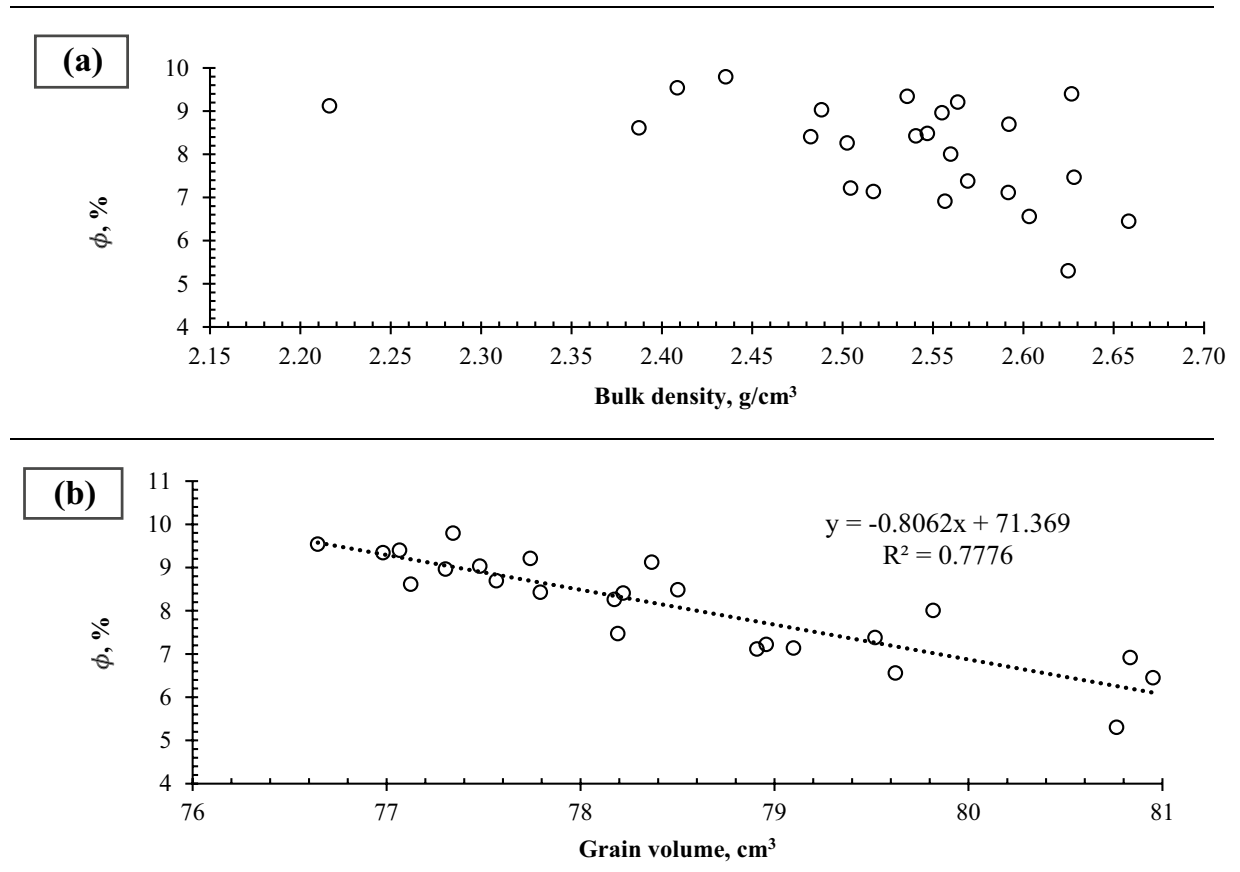

Fig. 9 Core samples' gas permeability and bulk density ultra-low permeability of the core samples and the required long time to reach the pressure equilibrium, the permeability was measured using the Autolab 1500, which applies the transient pulse decay method, and helium gas as pore fluid. It is worth mentioning that it took approximately $27 \mathrm{~h}$ to reach the pressure equilibrium before the permeability measurements. Increasing the temperature significantly decreases the permeability, where rock minerals expand, causing a reduction in the pore-throat and closure of the micro-fractures in the samples (Khalil et al. 2020; Ramezanian and Emadi 2020). It is worth noting that reaching the pressure equilibrium in the permeability measurement tests at the reservoir temperature $\left(82{ }^{\circ} \mathrm{C}\right)$ may take several weeks. Hence, the permeability measurements were conducted at the ambient temperature of $22^{\circ} \mathrm{C}$.

Measured permeability was plotted versus measured porosity in Fig. 10, demonstrating that the permeability-porosity relation of samples shows a very weak correlation owing to high heterogeneity. Shale samples are anisotropic and heterogenous that have variations in mineral compositions and complex pore networks even within the same shale formation. Thus, they are very heterogeneous regarding their pore size distribution, porosity, and 
Fig. 10 Porosity and permeability cross-plot

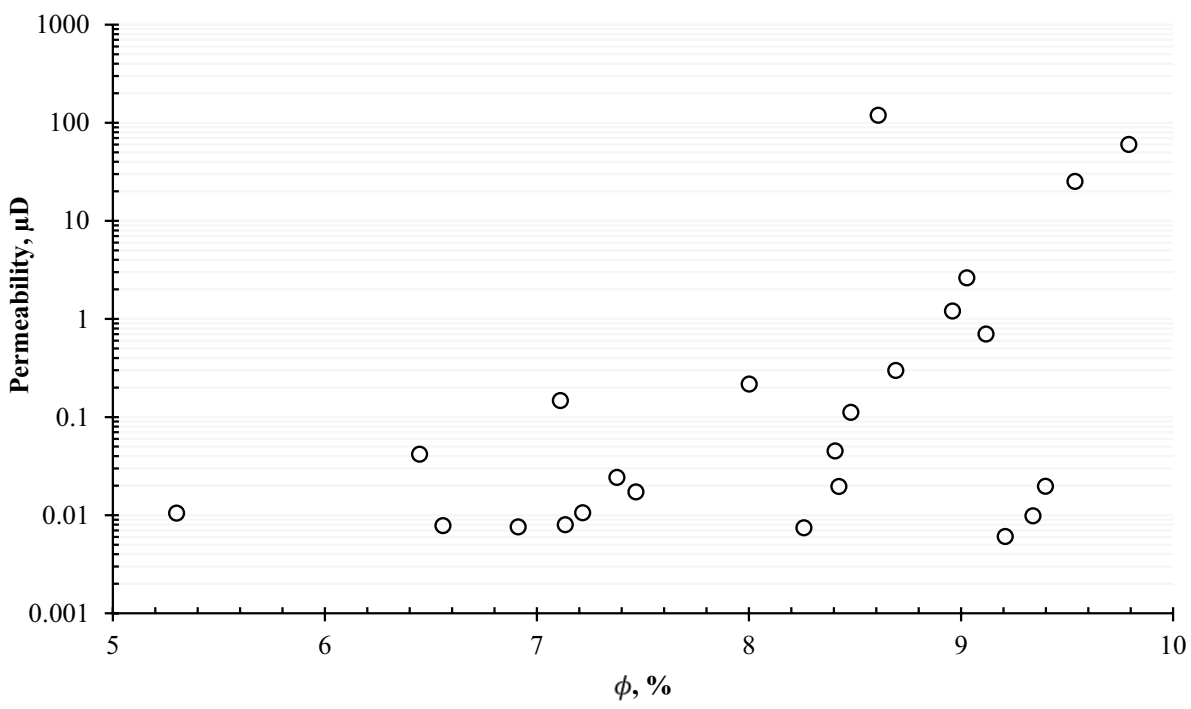

tortuosity level (Curtis et al. 2012). The complexity of these parameters makes the permeability-porosity correlation in shale samples challenging to achieve, and no or very weak permeability-porosity relationship can be attained.

Since the tested core samples in this study are from shale formation, Eagle Ford, where the pore sizes are in nanometers scale (Burrows et al. 2020) and the porosity is low, using the conventional procedures measuring the porosity results in underestimating the porosity value. Measuring shale porosity is strongly dependent on the gas injection pressure (Sun et al. 2016), where a minimum gas injection pressure of $1.48 \mathrm{MPa}$ and a longer diffusion time are required for accurate porosity measurements of plug samples. Applying gas injection pressures less than $1.38 \mathrm{MPa}$ results in underestimating the porosity values. For permeability measurement, Autolab 1500 system was used and this system involves the complex transient methods developed by the New England Research (NER) (Boitnott 1997). The tested samples' permeability was calculated using the multi-pulse transient method that reduces anisotropy and heterogeneity effects (Badrouchi et al. 2019), making it a reliable method to determine the permeability of shale samples. While measuring ultra-low-permeability core samples using a different method, such as aspike, would overestimate the permeability results compared to the multi-pulse method. The aspike method is more suitable for samples that have higher permeability values ( $>1 \mathrm{mD}$ ) (Badrouchi et al. 2019; Boitnott 1997).

Shale formations are well-known for their heterogeneity and properties, such as petrophysical and composition properties. They vary from one location to another, where the findings from one formation cannot be generalized to other shale rocks. In this study, core samples from Eagle Ford of West Texas were used. This formation is divided into the upper and lower units. The upper Eagle Ford is characterized by interlayered, burrowed, laminated light, and dark gray calcareous mudrock. The lower Eagle Ford can be described as organic-rich and laminated dark gray mudrock (EIA 2014; Hentz and Ruppel 2011). The upper Eagle ford is thicker than the lower Eagle Ford and displays higher calcite content and lower porosity (Inamdar et al. 2010). However, the Eagle Ford formation is generally considered a carbonaterich shale formation. The porosity can range from 1.5 to $12 \%$ (Cho et al. 2016; EIA 2014; Inamdar et al. 2010; Quirein et al. 2012; Sone and Zoback 2013a) and the ultra-low permeability of parallel-to-bedding samples vary from $3 \mathrm{nD}$ to $12 \mu \mathrm{D}$ (Heller et al. 2014).
Table 2 P- and S-wave velocities at different confining pressures

\begin{tabular}{|c|c|c|c|c|c|c|}
\hline \multirow[b]{2}{*}{$\begin{array}{l}\text { Confining pres- } \\
\text { sure, } \mathrm{MPa}\end{array}$} & \multicolumn{3}{|c|}{$\mathrm{V}_{\mathrm{P}}, \mathrm{m} / \mathrm{s}$} & \multicolumn{3}{|c|}{$\mathrm{V}_{\mathrm{S}}, \mathrm{m} / \mathrm{s}$} \\
\hline & Min & Max & Avg & Min & Max & Avg \\
\hline 13.79 & 4415 & 6127 & 5470 & 2515 & 3252 & 3013 \\
\hline 27.58 & 4453 & 6143 & 5511 & 2617 & 3258 & 3028 \\
\hline 41.37 & 4470 & 6201 & 5530 & 2625 & 3263 & 3037 \\
\hline 55.16 & 4483 & 6216 & 5552 & 2627 & 3275 & 3045 \\
\hline 68.95 & 4512 & 6206 & 5575 & 2635 & 3285 & 3055 \\
\hline
\end{tabular}


Table $3 \mathrm{P}$ - and S-wave velocities at 68.95 MPa confining pressure

\begin{tabular}{|c|c|c|c|}
\hline \multirow[b]{2}{*}{ Sample ID } & \multicolumn{3}{|c|}{ At $68.95 \mathrm{MPa}$ confining pressure } \\
\hline & $\mathrm{V}_{\mathrm{P}}, \mathrm{m} / \mathrm{s}$ & $\mathrm{V}_{\mathrm{S} 1}, \mathrm{~m} / \mathrm{s}$ & $\mathrm{V}_{\mathrm{S} 2}, \mathrm{~m} / \mathrm{s}$ \\
\hline 1 & 5560 & 3086 & 3067 \\
\hline 2 & 4512 & 2630 & 2639 \\
\hline 3 & 5513 & 3011 & 3072 \\
\hline 4 & 5167 & 2906 & 2960 \\
\hline 5 & 5679 & 3065 & 3023 \\
\hline 6 & 6188 & 3299 & 3271 \\
\hline 7 & 6028 & 3223 & 3217 \\
\hline 8 & 5716 & 3148 & 3106 \\
\hline 9 & 5806 & 3133 & 3099 \\
\hline 10 & 5963 & 3205 & 3156 \\
\hline 11 & 5487 & 3043 & 3080 \\
\hline 12 & 5520 & 3090 & 3034 \\
\hline 13 & 4785 & 2748 & 2777 \\
\hline 14 & 5564 & 3063 & 2940 \\
\hline 15 & 5744 & 3138 & 3110 \\
\hline 16 & 5354 & 3020 & 3021 \\
\hline 17 & 5558 & 3091 & 3027 \\
\hline 18 & 5036 & 2868 & 2833 \\
\hline 19 & 6200 & 3270 & 3260 \\
\hline 20 & 5472 & 2999 & 3067 \\
\hline 21 & 5395 & 2980 & 3026 \\
\hline 22 & 5334 & 2936 & 3001 \\
\hline 23 & 6206 & 3288 & 3255 \\
\hline 24 & 6011 & 3157 & 3207 \\
\hline
\end{tabular}

Table 2 presents $\mathrm{P}$-wave $\left(\mathrm{V}_{\mathrm{P}}\right)$ and $\mathrm{S}$-wave $\left(\mathrm{V}_{\mathrm{S}}\right)$ velocities measurements at different confining pressures; 13.79, 27.58, $41.37,55.16$, and $68.95 \mathrm{MPa}$. The results revealed that $\mathrm{V}_{\mathrm{S}}$ values are approximately $55 \%$ of $\mathrm{V}_{\mathrm{P}}$ values, and increasing the confining pressure up to $68.95 \mathrm{MPa}$ resulted in increasing the $\mathrm{V}_{\mathrm{P}}$ and $\mathrm{V}_{\mathrm{S}}$ by about $1.92 \%$ and $1.39 \%$, respectively.
The results show a linear relationship between $V_{P}$ and $V_{S}$ velocities. For instance, using Eq. (6), $\mathrm{V}_{\mathrm{P}}$ and $\mathrm{V}_{\mathrm{S}}$ velocities at $68.95 \mathrm{MPa}$ confining pressure (Table 3 ) can be correlated.

$V_{S}=0.357298207 V_{P}+1063.160813$

As shown in Fig. 11, the coefficient of determination, $R^{2}$, is high $(0.9727 \pm 0.012754)$, indicating a strong correlation between the two velocities. Table 4 shows the established correlations between $V_{p}$ and $V_{s}$ with the corresponding $R^{2}$ values at each applied confining pressure. It is worth noting that the two $\mathrm{S}$-wave velocities $\left(\mathrm{V}_{\mathrm{S} 1}\right.$ and $\left.\mathrm{V}_{\mathrm{S} 2}\right)$ are averaged to have a consistent $S$-wave velocity.

The variations in the tested samples' porosity and permeability make the relationship between the ultrasonic velocities and rock properties complex. However, the relationship between ultrasonic velocities $\left(\mathrm{V}_{\mathrm{P}}\right.$ and $\left.\mathrm{V}_{\mathrm{S}}\right)$ and porosity is generally inversely proportional. The same trend is observed between both velocities and the determined permeability of the samples (Fig. 12a and b). Moreover, the results indicate a direct relationship between velocities and bulk density of the samples (Fig. 12c). Additionally, the results showed that the relationships between $V_{S}$ and porosity, permeability, and bulk density are less scattered than $\mathrm{V}_{\mathrm{P}}$.

Two cycles of confining pressure were applied to the samples to investigate the effects of confining pressure on ultrasonic velocities and the dynamic elastic properties of the samples. The first cycle starts at $13.79 \mathrm{MPa}$ and ends at $68.95 \mathrm{MPa}$. The second cycle is the ramping down cycle (from 68.95 to $13.79 \mathrm{MPa}$ ). The effects of the two confining pressure cycles, ramping up and down, on $\mathrm{P}$ - and S-wave velocities and dynamic elastic moduli are illustrated in Fig. 13 and Fig. 14, respectively.

Ramping up the confining pressure from 13.79 to 68.95 MPa results in increasing both velocities and, in turn, increasing dynamic Young's modulus and Poisson's ratio (Fig. 14a and b), while decreasing the bulk compressibility
Fig. $11 \mathrm{P}$ - and S-wave relationship at $68.95 \mathrm{MPa}$ confining pressure

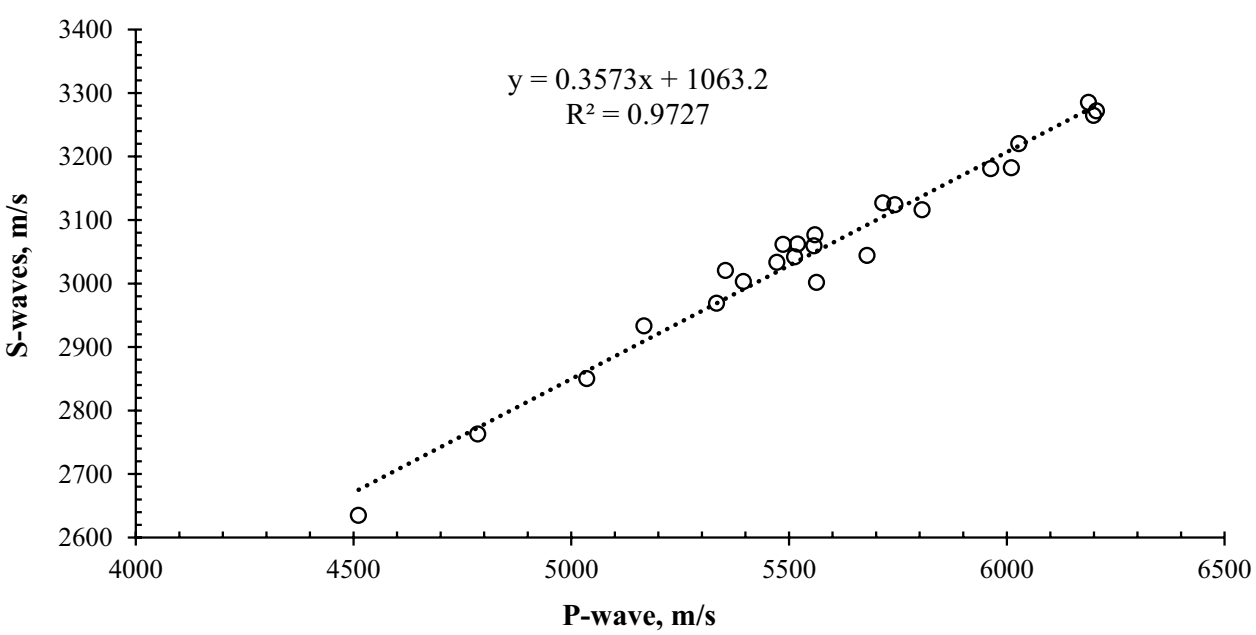


Table 4 Correlations of P- and $\mathrm{S}$-wave velocities at all applied confining pressures

\begin{tabular}{llll}
\hline $\begin{array}{l}\text { Confining pres- } \\
\text { sure, MPa }\end{array}$ & Determined equations, $\mathrm{m} / \mathrm{s}$ & $\mathrm{R}^{2}$ & Standard deviation \\
\hline 13.79 & $V_{S}=0.380923755 V_{P}+929.50206$ & 0.968572763 & 0.014628968 \\
27.58 & $V_{S}=0.358494377 V_{P}+1051.936411$ & 0.982697661 & 0.010141763 \\
41.37 & $V_{S}=0.350325847 V_{P}+1099.893107$ & 0.973810194 & 0.012248695 \\
55.16 & $V_{S}=0.351333154 V_{P}+1094.24756$ & 0.972744822 & 0.012538132 \\
68.95 & $V_{S}=0.357298207 V_{P}+1063.160813$ & 0.972732818 & 0.012753895 \\
\hline
\end{tabular}

Fig. 12 Ultrasonic velocities at 68.95 MPa confining pressure with: a porosity, b permeability, and $\mathbf{c}$ bulk density
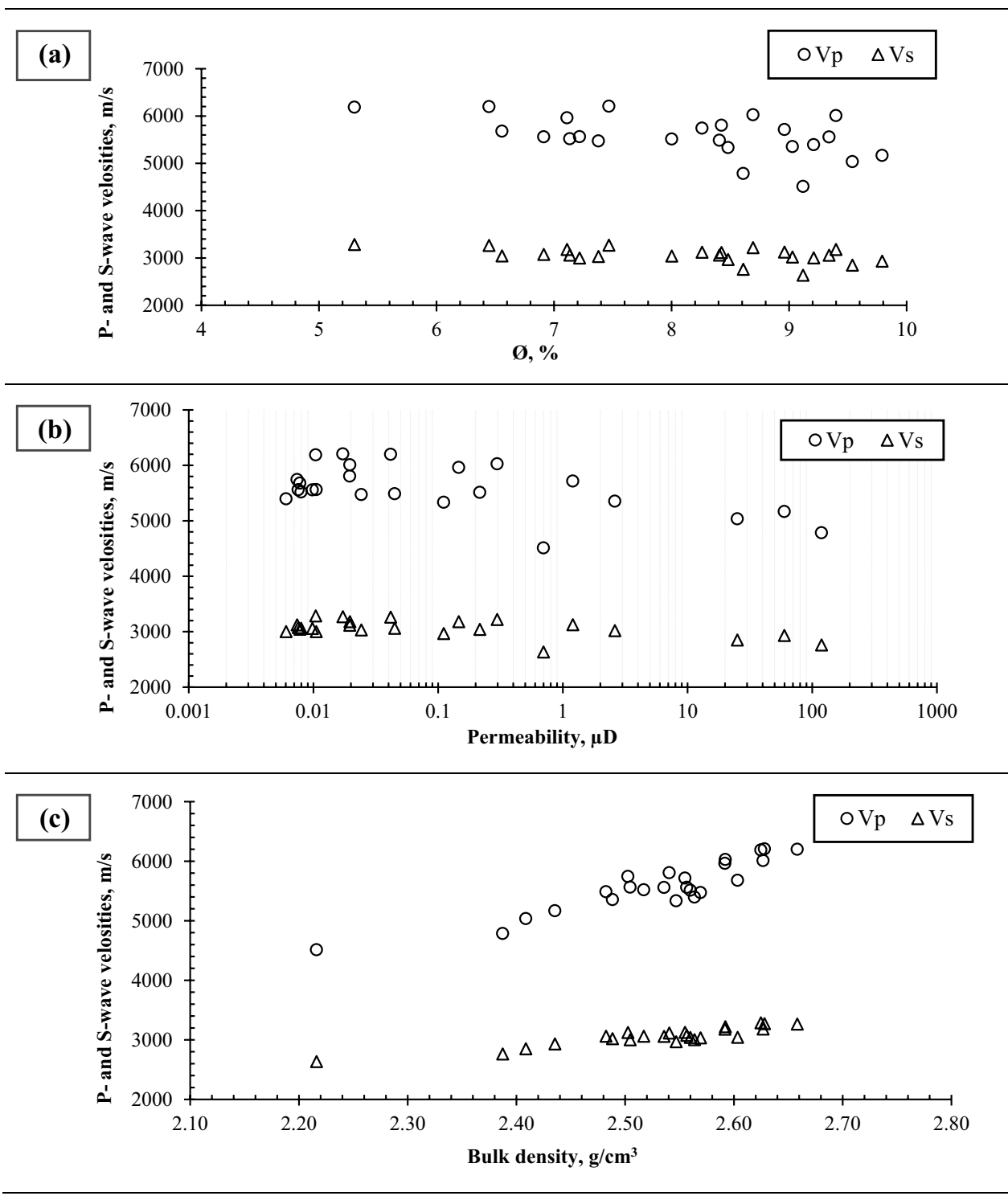

(Fig. 14c). Increasing the confining pressure results in increasing $\mathrm{P}$ - and S-wave velocities due to the samples' compaction and increasing the rock stiffness. One of the minerals present in the samples is kaolinite (Fig. 5), which is brittle (its Mohs' and absolute hardness are 2-2.5 and 2 , respectively) and can be easily broken (Ramezanian and Emadi 2020). The presence of this mineral results in more compaction in the samples when the confining pressure increases.

Effects of applying confining pressure cycles, ramping up and down (known as hysteresis loop), on both velocities are depicted in Fig. 13, where the loop is slightly opened, indicating that the deformation is non-elastic. The results demonstrated that during the ramping down cycle, P- and 
Fig. 13 Effect of confining pressure cycling and hysteresis loop on: a P-wave velocity and b S-wave velocity

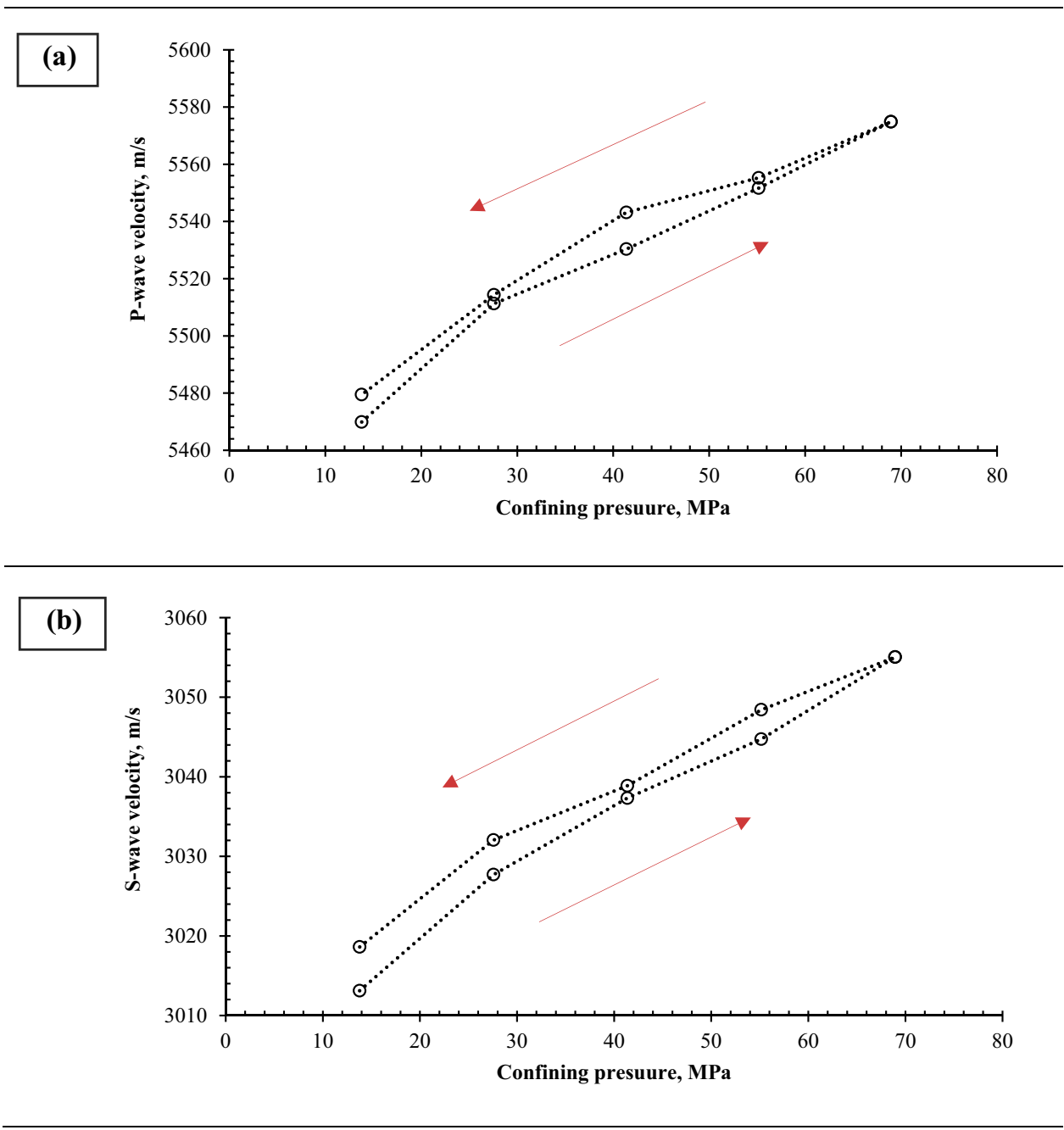

S-wave velocities are slightly higher than initial values when ramping up at any confining pressures due to unstable micropores and/or microcracks in the samples. These unstable micro-pores/micro-fractures are more likely to get partially closed during the ramping up cycle, where the confining pressure does not reach the collapsing pressure (Anselmetti and Eberli 1993; Luffel et al. 1993; Soete et al. 2015). Therefore, both velocities do not immediately return to the initial values during the ramping down cycle. However, loading and unloading rate of $0.023 \mathrm{MPa} / \mathrm{s}$, which is lower than the suggested rates (0.05-0.1 MPa/s) (Eloranta 2004; Guo et al. 2019; He et al. 2016; Ko and Kemeny 2007; Lin et al. 2016; Zhang et al. 2019), was applied to prevent any damage(s) inside the samples. Additionally, the confining pressure was held constant for two minutes before capturing the velocities. It is worth noting that all the samples were found undamaged after finishing the ultrasonic velocity measurement. Comparing the velocities at the two cycles, none of the samples showed a significant decrease in velocity while ramping down, demonstrating no fracture(s) was/were created in the test samples.

The changes in the P-and S-wave velocities and dynamic elastic moduli for both cycles are shown in Table 5. The results demonstrated that the changes in the velocities during the ramping up cycle are higher than the changes while ramping down (Table 5). For instance, when the confining pressure increased from 13.79 to $27.58 \mathrm{MPa}$, the change in $\mathrm{V}_{\mathrm{P}}$ is $0.757 \%$, while the change in $\mathrm{V}_{\mathrm{P}}$ when decreasing the confining pressure from 27.58 to $13.79 \mathrm{MPa}$ is $0.637 \%$.

Furthermore, inverse relationships exist between the dynamic Young's moduli with porosity (Fig. 15a) and permeability (Fig. 15b). Increasing porosity or permeability makes the rock sample less brittle. The existence of pore spaces and microcracks in the rock affects the rock-mechanical properties, such as uniaxial compressive strength (UCS) and tensile strength, where UCS and tensile strength of rock decrease with increasing porosity and permeability (Al-Harthi et al. 1999; Altawati and Emadi 2021; Gharahbagh and Fakhimi 2011; Koncagül 
Fig. 14 Effect of confining pressure cycling on: a dynamic Young's modulus, b dynamic Poisson's ratio, and $\mathbf{c}$ bulk compressibility
Table 5 Changes of increasing and decreasing the confining pressure on velocities and dynamic elastic moduli
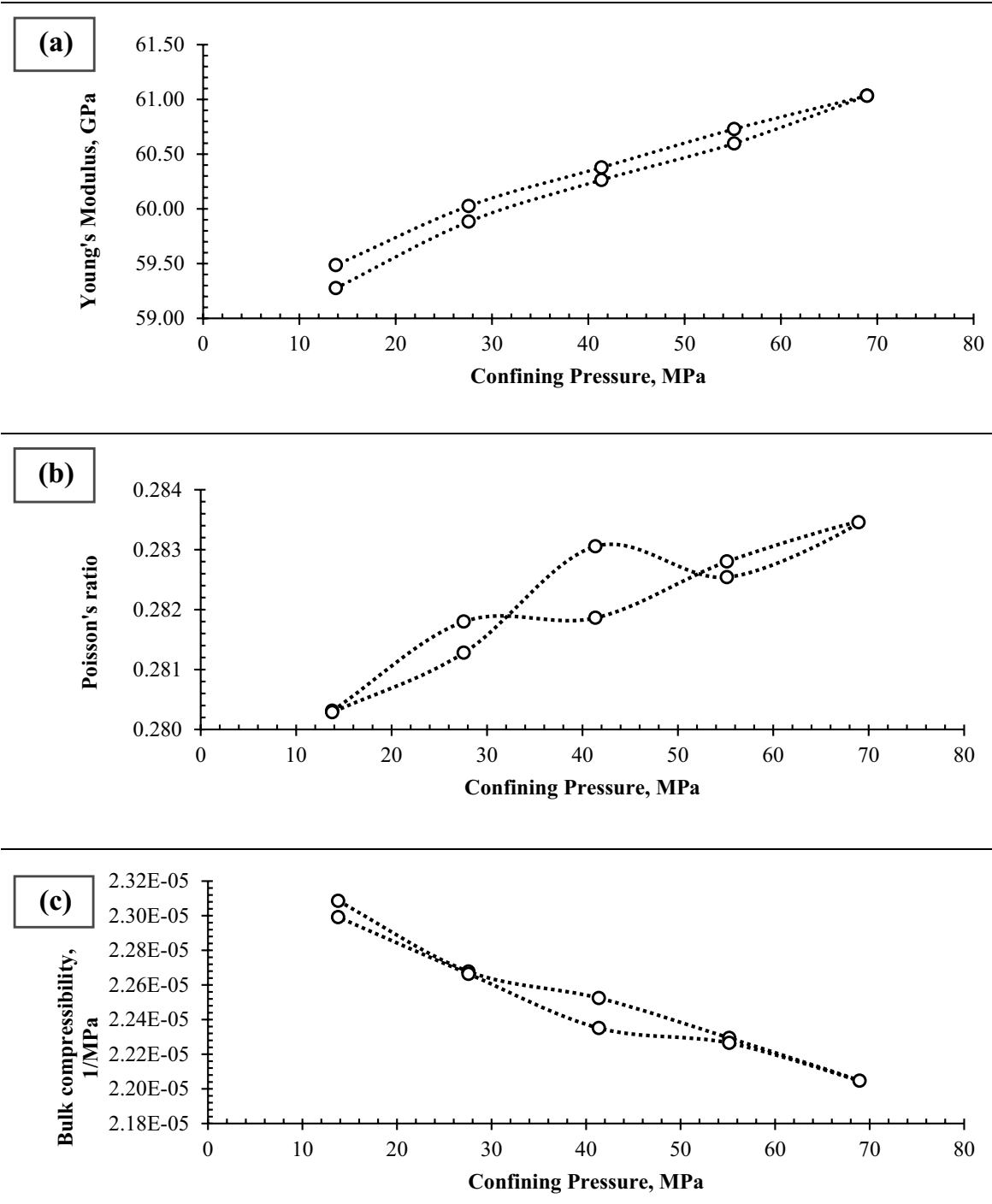

\begin{tabular}{lllllll}
\hline Cycle & $\begin{array}{l}\text { Confining pres- } \\
\text { sure, } \mathrm{MPa}\end{array}$ & $\Delta \mathrm{V}_{\mathrm{P}}, \%$ & $\Delta \mathrm{V}_{\mathrm{S}}, \%$ & $\Delta \mathrm{E}, \%$ & $\Delta v, \%$ & $\Delta \mathrm{C}_{\mathrm{b}}, \%$ \\
\hline Ramping up & 27.58 & 0.757 & 0.484 & 1.025 & 0.531 & -1.768 \\
& 41.37 & 1.105 & 0.803 & 1.667 & 0.553 & -2.431 \\
& 55.16 & 1.495 & 1.050 & 2.231 & 0.889 & -3.431 \\
& 68.95 & 1.919 & 1.392 & 2.966 & 1.122 & -4.502 \\
Ramping down & 68.95 & 1.741 & 1.207 & 2.602 & -0.323 & 4.111 \\
& 55.16 & 1.383 & 0.988 & 2.091 & -0.141 & 3.161 \\
& 41.37 & 1.163 & 0.671 & 1.500 & -0.768 & 2.786 \\
& 27.58 & 0.637 & 0.445 & 0.909 & -1.118 & 1.427 \\
\hline
\end{tabular}

and Santi 1999; Mohd 2009; Palchik and Hatzor 2004; Rajabzadeh et al. 2012). Thus, alteration in the rock brittleness occurs. Additionally, there are several factors that influence rock brittleness, such as mineral compositions, fluid type, and porosity (Wang and Gale 2009; Ye et al.
2020). Rock brittleness decreases with increasing porosity (Heidari et al. 2014; Jin et al. 2014; Mews et al. 2019; Ye et al. 2020). As a result, rock that is more brittle is stiffer, and it has lower porosity and permeability. 
Fig. 15 Dynamic Young's modulus with: a porosity and $\mathbf{b}$ permeability
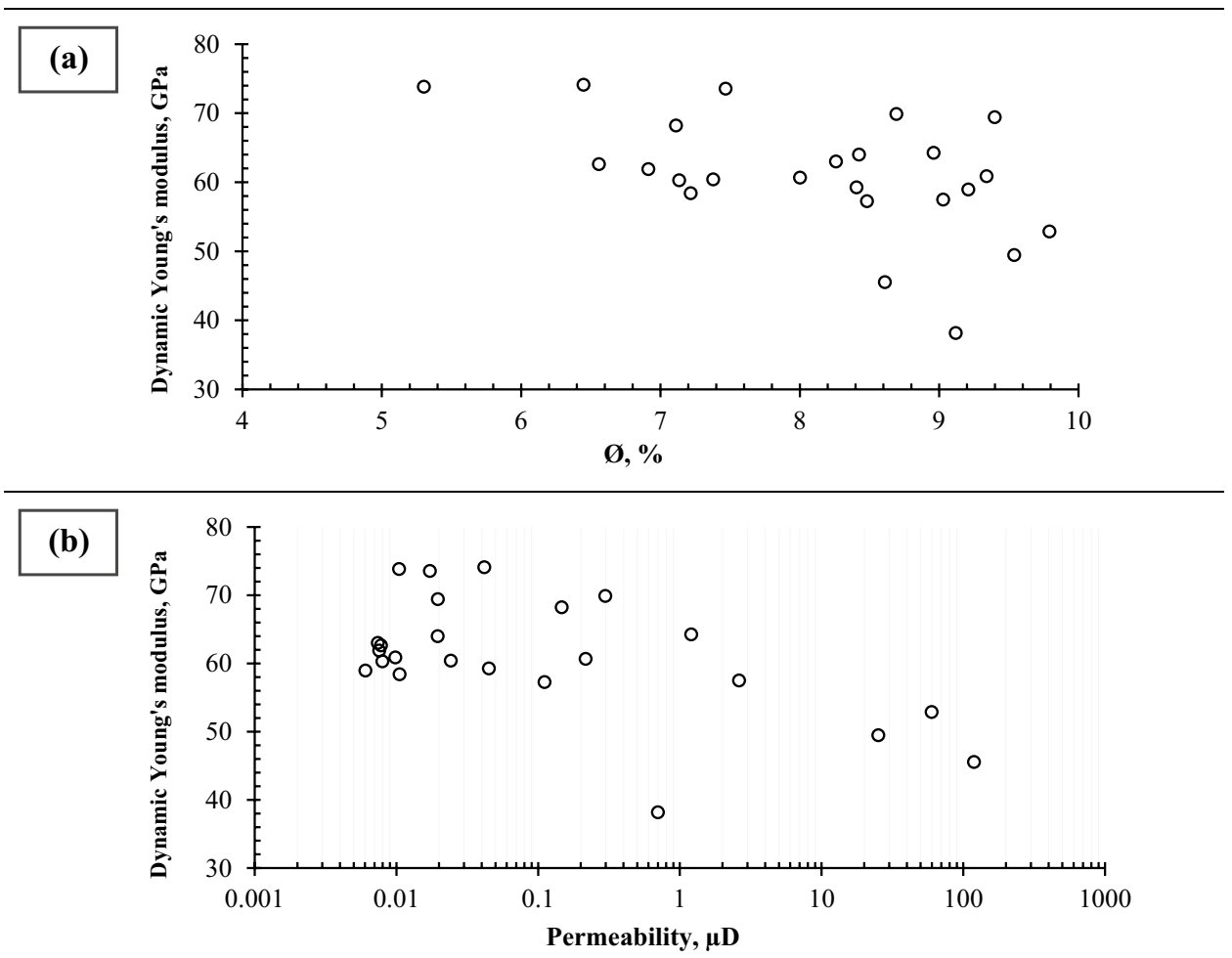

Fig. 16 Dynamic Young's modulus and Poisson's ratio vs. brittleness ratio of the samples at $68.95 \mathrm{MPa}$

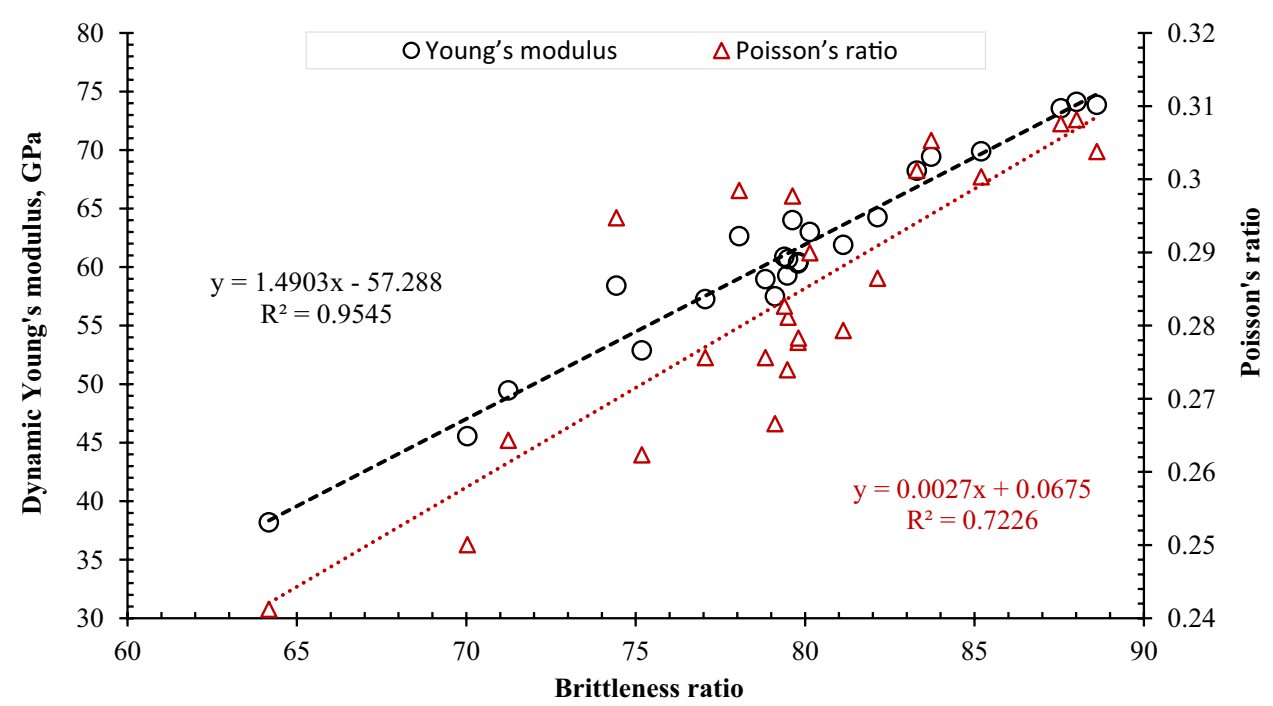

The brittleness ratios of samples are calculated using Eq. (5). As the confining pressure increases, the brittleness ratio increases, making test samples more rigid owing to the compaction. However, increasing the confining pressures beyond $13.79 \mathrm{MPa}$ does not significantly affect the brittleness ratio. Typically, having a lower value of Poisson's ratio makes the rock more brittle, and as Young's modulus increases, the rock becomes more brittle. A positive correlation exists between Young's modulus and brittleness ratio (standard error \pm 0.06935 ), as shown in Fig. 16.

Brittleness is an important parameter for well stimulation design and development in shale formations, such as hydraulic fracturing (Grieser and Bray 2007; Hou et al. 2015; Rickman et al. 2008; Wanniarachchi et al. 2017). Fractures tend to propagate well from a stiff zone toward a less-stiff zone and seem to penetrate the contact (Gudmundsson et al. 2010). Brittle shale has moderate-to-high Young's modulus and low Poisson's ratio, where natural 
fractures are more likely to exist. In contrast, ductile shale has low Young's modulus and high Poisson's ratio and acting as a seal stopping the hydrocarbon from moving out of the brittle shale interval (Grieser and Bray 2007; Rickman et al. 2008). Eagle Ford rocks have high strength (unconfined compressive strength $>120 \mathrm{MPa}$ ), moderate-to-high Young's modulus, and low Poisson's ratio (Alqahtani et al. 2013; Inamdar et al. 2010; Kolawole et al. 2019; Sone and Zoback 2013b). These characteristics develop the creation of fractures when compared with other clay-rich formations, making it a suitable candidate for implementing hydraulic fracturing operation.

\section{Summary and conclusions}

Some experimental parameters (e.g., using longer diffusion time of gas, utilizing higher gas injection pressure, applying complex transient method, and cycling the confining pressure) were not thoroughly considered when investigating the physical and dynamic elastic properties of the ultra-low permeability samples in the previous experimental studies. In this study, the experimental parameters of longer diffusion time and a higher injection pressure of helium, applying the multi-pulse method, and cycling the confining pressure were considered for porosity, permeability, and ultrasonic velocities measurements of twenty-four Eagle Ford core samples. This study provides and adds detailed information when it comes to experimental evaluations of rock physical and dynamic elastic properties of one of the most considerable unconventional resources in the U.S.A, the Eagle Ford formation, where direct measurements may not be costeffective or feasible. The following conclusions are drawn:

- The mineralogical compositions of the samples indicate that the samples are rich in calcite. The tested core samples have an average of $81.44 \%$ and $11.68 \%$ calcite and quartz, respectively, with a minor amount of clay minerals. Higher carbonate and quartz content in shale yields higher velocities, higher Young's modulus, and lower Poisson's ratio, which enhances the brittleness properties that are beneficial for well stimulation design such as hydraulic fracturing.

- The results revealed that the samples' porosity and permeability vary from $5.30 \%$ to $9.79 \%$, where $75 \%$ of the porosity data shows a greater porosity than $7.196 \%$. The samples' permeability ranges from $0.006 \mu \mathrm{D}$ to $11.8 \mu \mathrm{D}$, and $75 \%$ of the determined permeability data is below $0.398 \mu \mathrm{D}$. The results demonstrate a very weak correlation between permeability and porosity of Eagle Ford samples.

- P- and S-wave velocities were measured at five different confining pressures: 13.79, 27.58, 41.37, 55.16, and 68.95 MPa. The highest P- and S-wave velocities $(6206 \mathrm{~m} / \mathrm{s}$ and $3285 \mathrm{~m} / \mathrm{s})$ were measured at $68.95 \mathrm{MPa}$ confining pressure. Since a strong correlation is found between the two velocities, S-wave velocity can be confidently calculated using the less expensive P-wave velocity data. The results demonstrated inverse relationships between ultrasonic velocities and both porosity and permeability of the samples. However, the correlations between S-wave velocity with porosity, permeability, and bulk density are less scattered than P-wave velocity.

- The effects of applying cycles of confining pressure (known as hysteresis loop) were investigated in this study. Ramping up and down the confining pressure from 13.79 MPa to 68.95 MPa impact $\mathrm{P}$ - and $\mathrm{S}$-wave velocities and dynamic elastic moduli $\left(E_{d}, v_{d}, C_{b}\right)$. Increasing the confining pressure results in increasing both velocities owing to compaction of the samples and, in turn, increasing dynamic Young's modulus and Poisson's ratio while decreasing the bulk compressibility. Furthermore, the results demonstrated that both velocities are marginally higher than their initial values during the ramping down cycle. This is because of the unstable micro-pores and/ or micro-fractures in the samples, which partially closed during the ramping up cycle. As a result, they do not instantly return to their initial conditions during ramping down.

Acknowledgements The corresponding author wishes to express his greatest appreciation to King Saud University for its assistance and help throughout his studies.

\section{Declarations}

Conflict of interest On behalf of all the co-authors, the corresponding author states that there is no conflict of interest.

Funding No fund was provided for this study. The authors received no specific funding for this study.

Open Access This article is licensed under a Creative Commons Attribution 4.0 International License, which permits use, sharing, adaptation, distribution and reproduction in any medium or format, as long as you give appropriate credit to the original author(s) and the source, provide a link to the Creative Commons licence, and indicate if changes were made. The images or other third party material in this article are included in the article's Creative Commons licence, unless indicated otherwise in a credit line to the material. If material is not included in the article's Creative Commons licence and your intended use is not permitted by statutory regulation or exceeds the permitted use, you will need to obtain permission directly from the copyright holder. To view a copy of this licence, visit http://creativecommons.org/licenses/by/4.0/. 


\section{References}

Al-Harthi A, Al-Amri R, Shehata W (1999) The porosity and engineering properties of vesicular basalt in Saudi Arabia. Eng Geol $54: 313-320$

Aljamaan H, Al Ismail M, Kovscek AR (2017) Experimental investigation and grand canonical monte carlo simulation of gas shale adsorption from the macro to the nano scale. Journal of Natural Gas Science and Engineering 48:119-137. https://doi.org/10. 1016/j.jngse.2016.12.024

Aljamaan H, Alnoaimi K, Kovscek A (2013) In-depth experimental investigation of shale physical and transport properties. In: Unconventional Resources Technology Conference. Society of Exploration Geophysicists, American Association of Petroleum .... pp 1120-1129. doi:https://doi.org/10.1190/urtec2013-114

Allan AM, Clark AC, Vanorio T, Kanitpanyacharoen W, Wenk H-R (2016) On the evolution of the elastic properties of organic-rich shale upon pyrolysis-induced thermal maturationElasticity of pyrolyzed shale. Geophysics 81:D263-D281. https://doi.org/10. 1190/geo2015-0514.1

Alnoaimi K, Kovscek A (2013) Experimental and numerical analysis of gas transport in shale including the role of sorption. In: SPE Annual Technical Conference and Exhibition. Society of Petroleum Engineers. doi:https://doi.org/10.2118/166375-ms

Alnoaimi* KR, Duchateau C, Kovscek A (2014) Characterization and measurement of multi-scale gas transport in shale core samples. In: Unconventional Resources Technology Conference, Denver, Colorado, 25-27 August 2014. Society of Exploration Geophysicists, American Association of Petroleum .... pp 1140-1158. doi:https://doi.org/10.15530/urtec-2014-1920820

Alqahtani AA, Mokhtari M, Tutuncu AN, Sonnenberg S (2013) Effect of mineralogy and petrophysical characteristics on acoustic and mechanical properties of organic rich shale. In: SPE/AAPG/SEG Unconventional Resources Technology Conference. Society of Petroleum Engineers. doi:https://doi.org/10.1190/urtec2013-045

Altawati F, Emadi H (2021) Effects of cyclic cryogenic treatment on rock physical and mechanical properties of Eagle Ford shale samples-An experimental study. Journal of Natural Gas Science and Engineering 88:103772. https://doi.org/10.1016/j.jngse.2020. 103772

Amann-Hildenbrand A, Bertier P, Busch A, Krooss BM (2013) Experimental investigation of the sealing capacity of generic clay-rich caprocks. Int J Greenhouse Gas Control 19:620-641. https://doi. org/10.1016/j.ijggc.2013.01.040

Amyx J, Bass D, Whiting RL (1960) Petroleum reservoir engineering physical properties.

Anselmetti FS, Eberli GP (1993) Controls on sonic velocity in carbonates. Pure and Applied Geophysics PAGEOPH 141:287323. https://doi.org/10.1007/bf00998333

Aoudia K, Miskimins JL, Harris NB, Mnich CA (2010) Statistical analysis of the effects of mineralogy on rock mechanical properties of the Woodford shale and the associated impacts for hydraulic fracture treatment design. In: 44th US Rock Mechanics Symposium and 5th US-Canada Rock Mechanics Symposium. American Rock Mechanics Association. doi:https://doi. org/10.1201/noe0415444019-c206

API (1998) Recommended practices for core analysis (RP40). American Petroleum Institute (API), Washington, DC

Badrouchi N, Jabbari H, Badrouchi F, Tomomewo OS (2019) Comparing Different Methods of Permeability Measurement for Bakken Core Samples: Steady-State vs. Aspike \& Multi-Pulse. In: 53rd U.S. Rock Mechanics/Geomechanics Symposium, New York City, New York. American Rock Mechanics Association. doi:https://doi.org/10.1007/s00603-021-02559-z
Billiotte J, Yang D, Su K (2008) Experimental study on gas permeability of mudstones. Physics and Chemistry of the Earth, Parts a/b/c 33:S231-S236. https://doi.org/10.1016/j.pce.2008.10.040

Boitnott G (1997) Use of complex pore pressure transients to measure permeability of rocks. In: SPE Annual Technical Conference and Exhibition. Society of Petroleum Engineers. doi: https://doi. org/10.2118/38717-ms

Brace WF, Walsh JB, Frangos WT (1968) Permeability of granite under high pressure. J Geophys Res 73:2225-2236. https://doi. org/10.1029/jb073i006p02225

Burrows LC et al (2020) A literature review of CO2, natural gas, and water-based fluids for enhanced oil recovery in unconventional reservoirs. Energy Fuels 34:5331-5380. https://doi.org/10.1021/ acs.energyfuels.9b03658

Cao C, Li T, Shi J, Zhang L, Fu S, Wang B, Wang H (2016) A new approach for measuring the permeability of shale featuring adsorption and ultra-low permeability. Journal of Natural Gas Science and Engineering 30:548-556. https://doi.org/10.1016/j. jngse.2016.02.015

Chang C, Zoback MD, Khaksar A (2006) Empirical relations between rock strength and physical properties in sedimentary rocks. J Petrol Sci Eng 51:223-237. https://doi.org/10.1016/j. petrol.2006.01.003

Cho Y, Eker E, Uzun I, Yin X, Kazemi H (2016) Rock characterization in unconventional reservoirs: a comparative study of Bakken, Eagle Ford, and Niobrara Formations. In: SPE Low Perm Symposium. Society of Petroleum Engineers. doi:https://doi. org/10.2118/180239-ms

Cui X, Bustin AMM, Bustin RM (2009) Measurements of gas permeability and diffusivity of tight reservoir rocks: different approaches and their applications. Geofluids 9:208-223. https:// doi.org/10.1111/j.1468-8123.2009.00244.x

Curtis ME, Cardott BJ, Sondergeld CH, Rai CS (2012) Development of organic porosity in the Woodford Shale with increasing thermal maturity. Int J Coal Geol 103:26-31. https://doi.org/10. 1016/j.coal.2012.08.004

Dicker A, Smits R (1988) A practical approach for determining permeability from laboratory pressure-pulse decay measurements. In: International meeting on petroleum engineering. Society of Petroleum Engineers. doi:https://doi.org/10.2118/17578-ms

EIA (2014) Updates to the EIA Eagle Ford Play Maps.

Eloranta P (2004) Drill hole KFM01A: Indirect tensile strength test (HUT). SKB P04171, Svensk Kärnbränslehantering AB

Firouzi M, Alnoaimi K, Kovscek A, Wilcox J (2014) Klinkenberg effect on predicting and measuring helium permeability in gas shales. Int J Coal Geol 123:62-68. https://doi.org/10.1016/j. coal.2013.09.006

Fjar E, Holt RM, Raaen A, Horsrud P (2008) Petroleum related rock mechanics. Elsevier

Freund D (1992) Ultrasonic compressional and shear velocities in dry clastic rocks as a function of porosity, clay content, and confining pressure. Geophys J Int 108:125-135. https://doi.org/10.1111/j. 1365-246x.1992.tb00843.x

Gensterblum Y, Ghanizadeh A, Krooss BM (2014) Gas permeability measurements on Australian subbituminous coals: Fluid dynamic and poroelastic aspects. Journal of Natural Gas Science and Engineering 19:202-214. https://doi.org/10.1016/j.jngse.2014.04.016

Gharahbagh AE, Fakhimi A (2011) The effect of pore size on tensile and compressive strengths of rock: a bonded particle simulation. In: 45th US rock mechanics/geomechanics symposium. American Rock Mechanics Association

Grieser WV, Bray JM (2007) Identification of production potential in unconventional reservoirs. In: Production and Operations Symposium. Society of Petroleum Engineers 
Gudmundsson A, Simmenes TH, Larsen B, Philipp SL (2010) Effects of internal structure and local stresses on fracture propagation, deflection, and arrest in fault zones. J Struct Geol 32:1643-1655

Guo T, Zhang S, Gao J, Zhang J, Yu H (2013) Experimental study of fracture permeability for stimulated reservoir volume (SRV) in shale formation. Transp Porous Media 98:525-542. https://doi. org/10.1007/s11242-013-0157-7

Guo Y, Wang L, Chang X (2019) Study on the damage characteristics of gas-bearing shale under different unloading stress paths. PLoS ONE 14:e0224654. https://doi.org/10.1371/journal.pone.0224654

He J, Ling K (2016) Measuring permeabilities of Middle-Bakken samples using three different methods. Journal of Natural Gas Science and Engineering 31:28-38. https://doi.org/10.1016/j.jngse.2016. 03.007

He J, Lin C, Li X, Wan X (2016) Experimental investigation of crack extension patterns in hydraulic fracturing with shale. Sandstone and Granite Cores Energies 9:1018. https://doi.org/10.3390/en912 1018

He J, Ling K, Wu X, Pei P, Pu H (2019) Static and Dynamic Elastic Moduli of Bakken Formation. In: International Petroleum Technology Conference. International Petroleum Technology Conference. doi:https://doi.org/10.2523/19416-ms

Heidari M, Khanlari G, Torabi-Kaveh M, Kargarian S, Saneie S (2014) Effect of porosity on rock brittleness. Rock Mech Rock Eng 47:785-790. https://doi.org/10.1007/s00603-013-0400-0

Heller R, Vermylen J, Zoback M (2014) Experimental investigation of matrix permeability of gas shales experimental investigation of matrix permeability of gas shales. AAPG Bull 98:975-995. https://doi.org/10.1306/09231313023

Hentz TF, Ruppel SC (2011) Regional stratigraphic and rock characteristics of Eagle Ford Shale in its play area: Maverick Basin to east Texas Basin. In: AAPG Annual Convention and Exhibition. p 13

Hildenbrand A, Schlomer S, Krooss BM (2002) Gas breakthrough experiments on fine-grained sedimentary rocks. Geofluids 2:3-23. https://doi.org/10.1046/j.1468-8123.2002.00031.x

Holt RM, Nes OM, Stenebraten JF, Fjaer E (2012) Static Vs. Dynamic Behavior of Shale. In: 46th U.S. Rock Mechanics/Geomechanics Symposium, Chicago, Illinois. American Rock Mechanics Association.

Holt RM, Bauer A, Fjær E, Stenebråten J, Szewczyk D (2015) Relating static and dynamic mechanical anisotropies of shale. In: 49th US Rock Mechanics/Geomechanics Symposium. American Rock Mechanics Association.

Hou B, Chen M, Jin Y, Lin B, Diao C, Zhang X (2015) Optimum Condition of Hydraulic Fracture-Natural Fracture Interaction in Shale Block Experiments. In: 49th US Rock Mechanics/Geomechanics Symposium. American Rock Mechanics Association.

Inamdar AA, Ogundare TM, Malpani R, Atwood WK, Brook K, Erwemi AM, Purcell D (2010) Evaluation of stimulation techniques using microseismic mapping in the Eagle Ford Shale. In: Tight Gas Completions Conference. Society of Petroleum Engineers. doi:https://doi.org/10.2118/136873-ms

Jin X, Shah S, Truax J, Roegiers J-C (2014) A practical petrophysical approach for brittleness prediction from porosity and sonic logging in shale reservoirs. In: SPE annual technical conference and exhibition. doi:https://doi.org/10.2118/170972-ms

Jones SC (1997) A technique for faster pulse-decay permeability measurements in tight rocks. SPE Form Eval 12:19-26. https://doi.org/ $10.2118 / 28450$-pa

Khaksar A, Griffiths CM, McCann C (1999) Compressional- and shearwave velocities as a function of confining stress in dry sandstones. Geophys Prospect 47:487-508. https://doi.org/10.1046/j.13652478.1999.00146.x

Khalil R, Emadi H, Elwegaa K (2019) Investigation of Rock Properties of the Marcellus Formation-An Experimental Study. In:
SPE Eastern Regional Meeting. Society of Petroleum Engineers. doi:https://doi.org/10.2118/196580-ms

Khalil R, Ramezanian M, Altawati F, Emadi H (2020) Evaluating Pressure and Temperature Effects on Permeability and Elastic Properties of Wolfcamp Formation - An Experimental Study. In: 54th U.S. Rock Mechanics/Geomechanics Symposium, physical event cancelled. American Rock Mechanics Association.

Khazanehdari J, Sothcott J (2003) Variation in dynamic elastic shear modulus of sandstone upon fluid saturation and substitution. Geophysics 68:472-481. https://doi.org/10.1190/1.1567213

Kim TW, Ross CM, Guan KM, Burnham AK, Kovscek AR (2020) Permeability and porosity evolution of organic-rich shales from the green river formation as a result of maturation. SPE J 25:13771405. https://doi.org/10.2118/195366-pa

Klinkenberg L (1941) The permeability of porous media to liquids and gases. In: Drilling and production practice. American Petroleum Institute.

Ko T, Kemeny J (2007) Effect of confining stress and loading rate on fracture toughness of rocks. In: 1st Canada-US Rock Mechanics Symposium. American Rock Mechanics Association. doi:https:// doi.org/10.1201/noe0415444019-c76

Kolawole O, Esmaeilpour S, Hunky R, Saleh L, Ali-Alhaj HK, Marghani M (2019) Optimization of hydraulic fracturing design in unconventional formations: impact of treatment parameters. In: SPE Kuwait Oil \& Gas Show and Conference. Society of Petroleum Engineers. doi:https://doi.org/10.2118/198031-ms

Koncagül EC, Santi PM (1999) Predicting the unconfined compressive strength of the Breathitt shale using slake durability, Shore hardness and rock structural properties. Int J Rock Mech Min Sci 36:139-153

Kuila U, Dewhurst DN, Siggins AF, Raven MD (2011) Stress anisotropy and velocity anisotropy in low porosity shale. Tectonophysics 503:34-44. https://doi.org/10.1016/j.tecto.2010.09.023

Kuila U, McCarty DK, Derkowski A, Fischer TB, Prasad M (2014) Total porosity measurement in gas shales by the water immersion porosimetry (WIP) method. Fuel 117:1115-1129. https://doi.org/ 10.1016/j.fuel.2013.09.073

Kumar V, Sondergeld CH, Rai CS (2012) Nano to macro mechanical characterization of shale. In: SPE annual technical conference and exhibition. Society of Petroleum Engineers.

Lai B, Li H, Zhang J, Jacobi D, Georgi D (2016) Water-content effects on dynamic elastic properties of organic-rich shale. SPE J 21:635647. https://doi.org/10.2118/175040-pa

Li S, Dong M, Li Z (2009) Measurement and revised interpretation of gas flow behavior in tight reservoir cores. J Petrol Sci Eng 65:81-88. https://doi.org/10.1016/j.petrol.2008.12.017

Lin C, Pirie G, Trimmer DA (1986) Low permeability rocks: Laboratory measurements and three-dimensional microstructural analysis. Journal of Geophysical Research: Solid Earth 91:2173-2181. https://doi.org/10.1029/jb091ib02p02173

Lin C, He J, Li X, Wan X, Zheng B (2016) An experimental investigation into the effects of the anisotropy of shale on hydraulic fracture propagation. Rock Mech Rock Eng 50:543-554. https://doi.org/ 10.1007/s00603-016-1136-4

Luffel DL, Hopkins CW, Schettler PD (1993) Matrix Permeability Measurement of Gas Productive Shales. Paper presented at the All Days, Houston, Texas

Masri M, Sibai M, Shao JF, Mainguy M (2014) Experimental investigation of the effect of temperature on the mechanical behavior of Tournemire shale. Int J Rock Mech Min Sci 70:185-191. https:// doi.org/10.1016/j.ijrmms.2014.05.007

Metwally YM, Sondergeld CH (2011) Measuring low permeabilities of gas-sands and shales using a pressure transmission technique. Int J Rock Mech Min Sci 48:1135-1144. https://doi.org/10.1016/j. ijrmms.2011.08.004 
Mews KS, Alhubail MM, Barati RG (2019) A review of brittleness index correlations for unconventional tight and ultra-tight reservoirs. Geosciences 9:319

Miller SL (1992) Well log analysis of Vp and Vs in carbonates. CREWES Research Report 4:1-11

Mohd BK (2009) Compressive strength of vuggy oolitic limestones as a function of their porosity and sound propagation. Jordan J Earth Environ Sci 2:18-25

Mokhtari M, Tutuncu AN (2015) Characterization of anisotropy in the permeability of organic-rich shales. J Petrol Sci Eng 133:496-506. https://doi.org/10.1016/j.petrol.2015.05.024

Palchik V, Hatzor Y (2004) The influence of porosity on tensile and compressive strength of porous chalks. Rock Mech Rock Eng 37:331-341

Pan Z, Ma Y, Danesh NN, Connell LD, Sander R, Down DI, Camilleri M (2015) Measurement of Shale Anisotropic Permeability and Its Impact on Shale Gas Production. Paper presented at the All Days, Brisbane, Australia.

Profice S, Hamon G, Nicot B (2016) Low-Permeability Measurements: Insights. SPWLA-2003-v44n3a4 57: 30-40

Quirein JA, Murphy E, Praznik G, Witkowsky JM, Shannon S, Buller D (2012) A comparison of core and well log data to evaluate porosity, TOC, and hydrocarbon volume in the Eagle Ford Shale. In: SPE Annual Technical Conference and Exhibition. Society of Petroleum Engineers. doi:https://doi.org/10.2118/159904-ms

Rafavich F, Kendall CHSC, Todd TP (1984) The relationship between acoustic properties and the petrographic character of carbonate rocks. Geophysics 49:1622-1636. https://doi.org/10.1190/1.14415 70

Rajabzadeh M, Moosavinasab Z, Rakhshandehroo G (2012) Effects of rock classes and porosity on the relation between uniaxial compressive strength and some rock properties for carbonate rocks. Rock Mech Rock Eng 45:113-122

Ramezanian M, Emadi H (2020) Investigating effects of temperature and confining pressure on dynamic elastic properties and permeability-An experimental study. Geomechanics for Energy and the Environment 22:100179. https://doi.org/10.1016/j.gete.2020. 100179

Rickman R, Mullen MJ, Petre JE, Grieser WV, Kundert D (2008) A practical use of shale petrophysics for stimulation design optimization: All shale plays are not clones of the Barnett Shale. In: SPE annual technical conference and exhibition. Society of Petroleum Engineers. doi:https://doi.org/10.2118/115258-ms

Rushing JA, Newsham KE, Lasswell PM, Cox JC, Blasingame TA (2004) Klinkenerg-Corrected Permeability Measurements in Tight Gas Sands: Steady-State Versus Unsteady-State Techniques. Paper presented at the All Days, Houston, Texas

Shakouri A, Farzay O, Masihi M, Ghazanfari MH, Al-Ajmi AM (2019) An experimental investigation of dynamic elastic moduli and acoustic velocities in heterogeneous carbonate oil reservoirs. SN Applied Sciences 1:1023. https://doi.org/10.1007/ s42452-019-1010-6

Sigal RFF (2013) Mercury capillary pressure measurements on barnett core. SPE Reservoir Eval Eng 16:432-442. https://doi.org/ $10.2118 / 167607-$ pa
Soete $\mathrm{J}$ et al (2015) Acoustic properties in travertines and their relation to porosity and pore types. Mar Pet Geol 59:320-335. https://doi. org/10.1016/j.marpetgeo.2014.09.004

Sone H, Zoback MD (2013a) Mechanical properties of shale-gas reservoir rocks - Part 1: Static and dynamic elastic properties and anisotropy. Geophysics 78:D381-D392. https://doi.org/10.1190/ geo2013-0050.1

Sone H, Zoback MD (2013b) Mechanical properties of shale-gas reservoir rocks - Part 2: Ductile creep, brittle strength, and their relation to the elastic modulus. Geophysics 78:D393-D402. https:// doi.org/10.1190/geo2013-0051.1

Sun J, Dong X, Wang J, Schmitt DR, Xu C, Mohammed T, Chen D (2016) Measurement of total porosity for gas shales by gas injection porosimetry (GIP) method. Fuel 186:694-707. https://doi. org/10.1016/j.fuel.2016.09.010

Tanikawa W, Shimamoto T (2009) Comparison of Klinkenberg-corrected gas permeability and water permeability in sedimentary rocks. Int J Rock Mech Min Sci 46:229-238. https://doi.org/10. 1016/j.ijrmms.2008.03.004

Wang FP, Gale JF (2009) Screening criteria for shale-gas systems.

Wanniarachchi W, Ranjith P, Perera M, Nguyen J, Rathnaweera T (2017) An Experimental Study to Investigate the Effect of Mineral Composition on Mechanical Properties of Shale Gas Formations. In: 51st US Rock Mechanics/Geomechanics Symposium. American Rock Mechanics Association.

Wu W, Reece JS, Gensterblum Y, Zoback MD (2017) Permeability Evolution of Slowly Slipping Faults in Shale Reservoirs. Geophysical Research Letters 44:11,368-311,375. Doi :https://doi. org/10.1002/2017GL075506

Yao Y, Liu D, Che Y, Tang D, Tang S, Huang W (2010) Petrophysical characterization of coals by low-field nuclear magnetic resonance (NMR). Fuel 89:1371-1380. https://doi.org/10.1016/j.fuel.2009. 11.005

Ye Y, Tang S, Xi Z (2020) Brittleness evaluation in shale gas reservoirs and its influence on fracability. Energies 13:388

Zhai H, Chang X, Zhu W, Lei X, Xue Z (2021) Study on anisotropy of Longmaxi shale using hydraulic fracturing experiment. Sci China Earth Sci 64:260-277. https://doi.org/10.1007/s11430-020-9691-2

Zhang M, Takahashi M, Morin RH, Esaki T (2000) Evaluation and application of the transient-pulse technique for determining the hydraulic properties of low-permeability rocks - Part 2: Experimental application. Geotech Test J 23:91-99. https://doi.org/10. $1520 / g t j 11127 j$

Zhang Y, He J, Li X, Lin C (2019) Experimental study on the supercritical $\mathrm{CO} 2$ fracturing of shale considering anisotropic effects. J Petrol Sci Eng 173:932-940. https://doi.org/10.1016/j.petrol. 2018.10.092

Zoback MD (2010) Reservoir geomechanics. Cambridge University Press

Publisher's Note Springer Nature remains neutral with regard to jurisdictional claims in published maps and institutional affiliations. 